\title{
Regio- and Enantioselective $\mathrm{N}$-Allylations of Imidazole, Benzimidazole, and Purine Heterocycles Catalyzed by Single- Component Metallacyclic Iridium Complexes
}

\author{
Levi M. Stanley and John F. Hartwig \\ Department of Chemistry, University of Illinois, 600 South Mathews Avenue, Urbana, Illinois 61801 \\ John F. Hartwig: jhartwig@illinois.edu
}

\section{Abstract}

Highly regio- and enantioselective iridium-catalyzed $N$-allylations of benzimidazoles, imidazoles, and purines have been developed. $N$-Allylated benzimidazoles and imidazoles were isolated in high yields (up to 97\%) with high branched-to-linear selectivity (up to 99:1) and enantioselectivity (up to 98\% ee) from the reactions of benzimidazole and imidazole nucleophiles with unsymmetrical allylic carbonates in the presence of single component, ethylene-bound, metallacyclic iridium catalysts. $\mathrm{N}$ Allylated purines were also obtained in high yields (up to 91\%) with high N9:N7 selectivity (up to 96:4), high branched-to-linear selectivity (98:2), and high enantioselectivity (up to $98 \%$ ee) under similar conditions. The reactions encompass a range of benzimidazole, imidazole, and purine nucleophiles, as well as a variety of unsymmetrical aryl, heteroaryl, and aliphatic allylic carbonates. Competition experiments between common amine nucleophiles and the heterocyclic nitrogen nucleophiles studied in this work illustrate the effect of nucleophile $p \mathrm{~K}_{\mathrm{a}}$ on the rate of iridiumcatalyzed $N$-allylation reactions. Kinetic studies on the allylation of benzimidazole catalyzed by metallacyclic iridium-phosphoramidite complexes, in combination with studies on the deactivation of these catalysts in the presence of heterocyclic nucleophiles, provide insight into the effects of the structure of the phosphoramidite ligands on the stability of the metallacyclic catalysts. The data obtained from these studies has led to the development of $\mathrm{N}$-allylations of benzimidazoles and imidazoles in the absence of an exogenous base.

\section{Introduction}

Enantioselective, metal-catalyzed allylic amination is a useful method to prepare enantiomerically enriched allylic amines from a variety of nitrogen nucleophiles and allylic electrophiles. ${ }^{1-10}$ However, metal-catalyzed enantioselective $N$-allylation of less nucleophilic reagents, such as nitrogen-containing heterocycles, remains underdeveloped, despite the synthetic utility of the products. ${ }^{11,12}$ Currently, the most prominent catalysts for enantioselective $N$-allylation of nitrogen-containing heterocycles are chiral, non-racemic palladium complexes. A report by Trost and co-workers on the palladium-catalyzed enantioselective $N$-allylation of a guanine equivalent with a cyclic meso-diester as a key step in the total synthesis of the carbocyclic nucleoside (-)-carbovir illustrates the utility of enantioselective $N$-allylations of heterocyclic nucleophiles. ${ }^{13}$ Additional reports detailing enantioselective palladium-catalyzed $N$-allylations of heterocyclic nucleophiles have

Correspondence to: John F. Hartwig, jhartwig@illinois.edu.

Ir-Catalyzed $N$-Allylation of Heterocycles

Supporting Information Available: Experimental procedures, characterization data, and complete reference 48. This material is available free of charge via the Internet at http://pubs.acs.org. 
followed, but these processes are limited by the inability to generate chiral allylic substitution products selectively from achiral linear allylic esters. ${ }^{14-16}$

Over the past decade, enantioselective iridium-catalyzed allylic amination has emerged as a powerful complement to enantioselective, palladium-catalyzed allylic amination reactions. ${ }^{17-40}$ Iridium-catalyzed allylic amination reactions make possible the synthesis of enantioenriched allylic amines from achiral linear reactants. However, enantioselective reactions that selectively form branched allylic substitution products from nitrogen heterocycles, other than phthalimide, and achiral linear reactants are unknown (eq 1). ${ }^{41}$ These reactions would create a direct approach to enantioenriched heterocycles that cannot be accessed by hydrogenation of a $\mathrm{C}=\mathrm{N}$ double bond or classical resolution of racemic material and that can be transformed into a series of further functionalized materials. ${ }^{42}$ Access to enantiomerically enriched $N$-allylated heterocycles from unsymmetrical allylic electrophiles is presently limited to rhodium-catalyzed reactions of $N^{3}$-benzoyl thymine or a dihydropyrimidin-2(3H)-one with enantioenriched secondary allylic carbonates with retention of configuration. ${ }^{43,44}$

The products of these reactions are relevant to medicinal chemistry because of the established biological activity associated with benzimidazole,${ }^{45}$ imidazole,${ }^{46}$ and purine derivatives. ${ }^{47}$ For example, the chiral $N$-allyl imidazoles are advanced intermediates to a class of kinase inhibitors, ${ }^{48,49}$ while the $N$-allyl purines are chiral precursors to a family of antiretroviral drugs. ${ }^{50-53}$ Furthermore, the $N$-allyl heterocycle products contain a terminal olefin that makes possible the straightforward syntheses of $\alpha$-imidazolyl alcohol, $\alpha$-purinyl alcohol, $\beta$-imidazolyl alcohol, and $\beta$-purinyl alcohol derivatives.

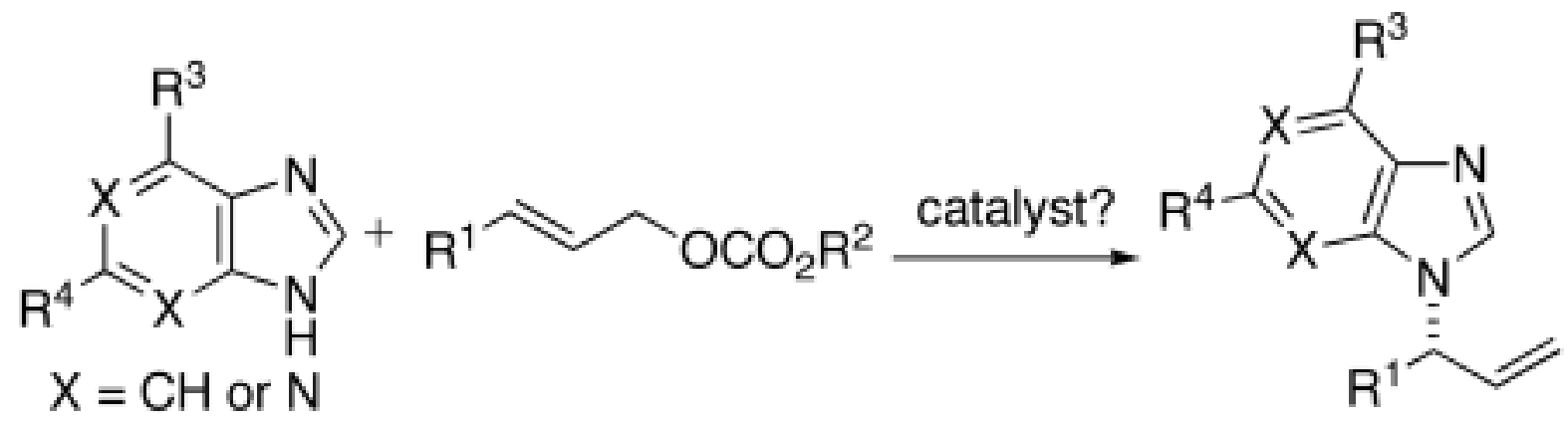

We report the formation of enantioenriched, branched $N$-allyl heterocycles from reactions of benzimidazoles, imidazoles, and purines with achiral linear allylic carbonates in the presence of single-component iridium catalysts. The new iridium catalysts, along with the proper base, improve the efficiency of the allylation process, overcome isomerization of the product to the enamine, and lead to the formation of products with high enantioselectivity, high regioselectivity for addition to the more substituted position of the allyl electrophile, and with high selectivity for the addition to the N9 position over the N7 position of purines. A combination of competition experiments, kinetic studies, and experiments on catalyst deactivation create an improved understanding of the activity and stability of the metallacyclic iridium catalysts. In addition to revealing a new class of asymmetric $N$-allylation reactions, these studies led to the identification of an appropriate iridium catalyst for base-free $\mathrm{N}$ allylations of benzimidazole and imidazole nucleophiles. 


\section{Results and Disscussion}

\section{Catalyst Identification and Optimization of Reaction Conditions}

We previously showed that complex 1 (Figure 1), which is generated from $[\operatorname{Ir}(\mathrm{COD}) \mathrm{Cl}]_{2}$, phosphoramidite ligand $\mathbf{L} \mathbf{1}$ in Figure 1, and base, catalyzes asymmetric allylic substitutions with weakly basic nitrogen nucleophiles (arylamines), as well as basic nitrogen nucleophiles (benzylic amines and alkylamines), to form branched allylic substitution products. ${ }^{38}$ Thus, initial studies to develop iridium-catalyzed asymmetric $N$-allylations of nitrogen heterocycles containing acidic N-H bonds were conducted with preformed metallacycle $\mathbf{1}$ as catalyst. The model reaction of methyl cinnamyl carbonate (3a) with benzimidazole (4a) was selected to test the viability of metallacycle $\mathbf{1}$ as a catalyst for allylic substitutions with nitrogen-containing heterocycles.

In contrast to reactions of amines with methyl cinnamyl carbonate, no reaction occurred between benzimidazole and methyl cinnamyl carbonate (Table 1, entry 1). The same reaction with added base did occur, but this reaction conducted without the proper choice of base led to a mixture of $N$-allylazole and enamine from isomerization of the initial $N$-allylazole product or to the enamine as the exclusive product. For example, the reaction of methyl cinnamyl carbonate with benzimidazole in the presence of $2 \mathrm{~mol} \% \mathbf{1}, 1 \mathrm{~mol} \%[\operatorname{Ir}(\mathrm{COD}) \mathrm{Cl}]_{2}$ to trap $\mathbf{L 1}$ after dissociation, and 1.0 equivalent $\mathrm{Cs}_{2} \mathrm{CO}_{3}$ gave enamine $7 \mathbf{a}$ as the only reaction product (entry 2). ${ }^{54}$ In contrast, the reaction of methyl cinnamyl carbonate with benzimidazole in the presence of 1.0 equivalent of $\mathrm{K}_{3} \mathrm{PO}_{4}$ and $2 \mathrm{~mol} \% \mathbf{1}$ and $1 \mathrm{~mol} \%[\mathrm{Ir}(\mathrm{COD}) \mathrm{Cl}]_{2}$ gave the branched $N$-allylation product $5 \mathbf{a}$ in high yield, branched-to-linear ratio and enantioselectivity (entry 3). The reaction catalyzed by 2 mol \% 1 generated in situ from $4 \mathrm{~mol} \% \mathbf{L 1}$ and $2 \mathrm{~mol}$ $\%[\operatorname{Ir}(\mathrm{COD}) \mathrm{Cl}]_{2}$ also occurred to high conversion and with high selectivities (entry 4$){ }^{35}$ However, reactions of benzimidazole conducted with lower amounts of the catalyst precursors $\left(1 \mathrm{~mol} \% 1\right.$ and $\left.0.5 \mathrm{~mol} \%[\operatorname{Ir}(\mathrm{COD}) \mathrm{Cl}]_{2}\right)$ formed the branched allylic substitution product $\mathbf{5 a}$ in lower yield due to the formation of substantial amounts of enamine 7a (entry 5). Likewise, substantial isomerization of allylic amine 5a to enamine 7a occurred when the catalyst was generated in situ from $2 \mathrm{~mol} \% \mathbf{L 1}$ and $1 \mathrm{~mol} \%[\operatorname{Ir}(\mathrm{COD}) \mathrm{Cl}]_{2}$ (entry 6). This isomerization of the allylation product to the enamine was not observed during studies of the allylation of amines reported previously. $33,35,38,40$

To improve the efficiency of the allylation process further, we investigated reactions catalyzed by the ethylene adduct $\mathbf{2 a}$ of the active metallacyclic catalyst, which was recently identified as part of mechanistic studies of iridium-catalyzed allylation. ${ }^{20}$ Catalyst $\mathbf{2 a}$ offered the potential for $N$-allylations of nitrogen heterocycles to occur with lower amounts of iridium and without isomerization to the corresponding enamine because $\left[\operatorname{Ir}(\mathrm{COD}) \mathrm{Cl}_{2}\right.$ is not necessary to trap the phosphoramidite ligand $\mathbf{L} \mathbf{1}$ after dissociation from metallacycle $\mathbf{1}$. The four-coordinate iridium-phosphoramidite complex $[\operatorname{Ir}(\mathrm{COD})(\mathbf{L 1}) \mathrm{Cl}]$ is not an active catalyst for the allylic substitution reaction, but is a catalyst for the isomerization process. After $4 \mathrm{~h}$ in the presence of $2 \mathrm{~mol} \%[\operatorname{Ir}(\mathrm{COD})(\mathbf{L 1}) \mathrm{Cl}], 36 \%$ of pure $N$-allyl benzimidazole $\mathbf{5 a}$ in THF solvent converted to the isomeric enamine 7a. This observation is similar to the known isomerizations of allyl ethers and allylamides in the presence of the iridium-phosphine complex $\left[\operatorname{Ir}(\mathrm{COD})\left(\mathrm{PCy}_{3}\right) \mathrm{Cl}\right]$. 54,55 In addition to avoiding the species that leads to isomerization of $\mathbf{5 a}$ to $7 \mathbf{a}$, catalyst $\mathbf{2 a}$ would be simpler to use because an additive is not required to form the active iridium catalyst prior to addition of the reagents.

Indeed, the reaction of methyl cinnamyl carbonate with benzimidazole in the presence of 2 mol \% of the single-component catalyst $\left[\operatorname{Ir}(\mathrm{COD})\left(\kappa^{2}-\mathbf{L 1}\right)(\right.$ ethylene)] (2a), or the related catalyst [ $\operatorname{Ir}(\mathrm{COD})\left(\kappa^{2}-\mathbf{L} 2\right)($ ethylene)] (2b) generated from the ortho-anisyl substituted phosphoramidite $\mathbf{L 2},{ }^{28,36}$ occurred in high yield, branched-to-linear selectivity, and enantioselectivity, and without isomerization of the branched substitution product 5a to the 
enamine 7a (entries 7 and 8). Furthermore, the correct choice of base was necessary for the model reaction catalyzed by $\mathbf{2 a}$ to occur with acceptable rates of reaction and high selectivities. The reaction of methyl cinnamyl carbonate with benzimidazole in the presence of $\mathrm{K}_{3} \mathrm{PO}_{4}$ or $\mathrm{Na}_{3} \mathrm{PO}_{4}$ gave product $\mathbf{5 a}$ in high yield and selectivity over 2-3 h reaction times (entries 7 and 9), but the same reaction in the presence of $\mathrm{Li}_{3} \mathrm{PO}_{4}$ occurred to only $33 \%$ conversion after $3 \mathrm{~h}$ (entry 10). In contrast, reactions conducted in the presence of alkali metal alkoxide bases resulted in complete conversion of the methyl cinnamyl carbonate, but approximately $35 \%$ of the branched allylation product $\mathbf{5 a}$ converted to the isomeric enamine $\mathbf{7 a}$ in the presence of $\mathrm{KO} t-\mathrm{Bu}$ (entry 11) and all of $\mathbf{5 a}$ converted to $\mathbf{7 a}$ during reactions conducted in the presence of $\mathrm{NaO} t$-Bu (entry 12). The model reaction catalyzed by $\mathbf{2 a}$ also occured in the presence of alkali carbonate bases, and the rates of reaction parallel the solubility and ionic charcter of these bases. For example, the reaction of methyl cinnamyl carbonate with benzimidazole in the presence of $\mathrm{Cs}_{2} \mathrm{CO}_{3}$ occurred with complete conversion after $3 \mathrm{~h}$ (entry 13), while the reactions conducted in the presence of $\mathrm{K}_{2} \mathrm{CO}_{3}$ and $\mathrm{Na}_{2} \mathrm{CO}_{3}$ occurred to $73 \%$ and $48 \%$ conversion after $3 \mathrm{~h}$ (entries 14 and 15). The high yield, high selectivities, and absence of isomerization from reactions conducted with catalysts $2 \mathbf{a}$ and $\mathbf{2 b}$ and the inexpensive base $\mathrm{K}_{3} \mathrm{PO}_{4}$ led us to study the scope of the iridium-catalyzed $N$-allylation process with a variety of allylic carbonate electrophiles and benzimidazole nucleophiles in the presence of complexes $\mathbf{2 a}$ and $\mathbf{2} \mathbf{b}$ as catalyst and $\mathrm{K}_{3} \mathrm{PO}_{4}$ as base

\section{Enantioselective $\mathbf{N}$-Allylation of Benzimidazoles}

Results from the $N$-allylation of benzimidazoles with a series of allylic carbonates under the optimized conditions are summarized in Table 2. Reactions of benzimidazole with a variety of electron-rich or electron-neutral cinnamyl carbonates containing meta or para substituents gave the corresponding chiral benzimidazole products in high yields with good to excellent regio- and enantioselectivities (Table 2, entries 1-5). The chiral benzimidazoles produced from the allylations of benzimidazole with allylic carbonates $\mathbf{3 a - 3 e}$ catalyzed by metallacycle $\mathbf{2 a}$ occurred with 96:4 to 99:1 branched-to-linear regioselectivity, and the branched isomers were isolated in $84-94 \%$ yield with $95-97 \%$ enantiomeric excess.

However, the reaction of methyl ortho-methoxycinnamyl carbonate $3 \mathbf{f}$ with benzimidazole catalyzed by metallacycle 2a occurred with modest enantioselectivity ( $80 \%$ ee, entry 6 ). This result is consistent with lower enantioselectivities for iridium-catalyzed allylic substitution reactions of ortho-substituted cinnamyl carbonates reported previously. ${ }^{9,35,40}$ However, the reaction of benzimidazole with methyl ortho-methoxycinnamyl carbonate in the presence of 2 mol \% $\mathbf{2 b}$, instead of $\mathbf{2 a}$, occurred with high enantioselectivity (92\% ee, entry 7 ).

Heteroaryl and aliphatic allyl carbonates also reacted selectively with benzimidazole. The chiral $N$-allylic benzimidazole produced from the reaction of the 2-furyl-substituted allyl carbonate $\mathbf{3 g}$ with benzimidazole was isolated in $90 \%$ yield with $94: 6$ branched-to-linear selectivity and $96 \%$ ee (entry 8 ). The product from the reaction of hex-2-enyl methyl carbonate 3h with benzimidazole was isolated in $90 \%$ yield with $92: 8$ branched-to-linear selectivity and 94\% ee (entry 9).

The allylation of benzimidazole occurred more slowly and with lower selectivity with cinnamyl carbonates that are substituted with strongly electron-withdrawing substituents in the para position. For example, the reaction of benzimidazole with methyl paratrifluoromethylcinnamyl carbonate in the presence of 4 mol \% $\mathbf{2 a}$ occurred to only $21 \%$ conversion after $8 \mathrm{~h}$ at $50^{\circ} \mathrm{C}$, and the enamine $7 \mathbf{i}$ was the only observable product of the reaction (Scheme 1, eq 1). The allylation of benzimidazole with methyl para-trifluoromethylcinnamyl carbonate occurred to completion in the presence of $4 \mathrm{~mol} \% \mathbf{2 b}$ (eq 2). However, the addition of 1-phenylpropyne was necessary to prevent complete isomerization of the branched allylic 
substitution product $\mathbf{5 i}$ to the enamine $7 \mathbf{7},{ }^{56}$ and the yield of $\mathbf{5 i}$ was only $25 \%$ by ${ }^{1} \mathrm{H}$ NMR spectroscopy under optimized conditions.

Additional benzimidazole nucleophiles underwent the allylic substitution process in moderate to high yield and with high enantioselectivity. In these cases, the most active and selective catalyst depended on the nucleophile. Some of these reactions occurred in higher yields with higher selectivities in the presence of the ortho-anisyl catalyst $\mathbf{2 b}$. For example, the reaction of 2-phenylbenzimidazole with methyl cinnamyl carbonate in the presence of $2 \mathrm{~mol} \%$ of $\mathbf{2 b}$ gave product $\mathbf{5 j}$ in $96 \%$ ee (Table 3 , entry 2 ), while the reaction conducted with the parent catalyst 2a formed this product in $86 \%$ ee (entry 1 ). Likewise, reactions of 2-

methylbenzimidazole with methyl cinnamyl carbonate $3 \mathbf{a}$ and the hindered aliphatic carbonate $\mathbf{3 j}$ occurred to low conversions when conducted with catalyst 2a (entries 3 and 5), but formed the chiral benzimidazole $\mathbf{5 k}$ and $\mathbf{5 l}$ in high yields and with high selectivities in the presence of catalyst $\mathbf{2 b}$ (entries 4 and 6). However, the reaction of methyl cinnamyl carbonate with 2chlorobenzimidazole to form product $\mathbf{5 m}$ was more selective for the branched substitution product when conducted with parent catalyst $\mathbf{2 a}$. The branched-to-linear ratio for the reaction of methyl cinnamyl carbonate with 2-chlorobenzimidazole at $50{ }^{\circ} \mathrm{C}$ in the presence of $\mathbf{2 a}$ was 85:15 (entry 7), but was only 58:42 in the presence of $\mathbf{2 b}$ (entry 8). A further increase in the branched-to-linear selectivity occurred when this reaction was conducted at room temperature $(\mathbf{5 : 6}=89: 11$, entry 9).

The reactions of 2-hydroxylmethylbenzimidazole $4 \mathbf{e}$ with methyl cinnamyl carbonate $3 \mathbf{a}$ were also affected by $N$ - versus $O$-allylation. In the presence of $2 \mathrm{~mol} \% \mathbf{2 a}$, this reaction occurred with $88: 12$ branched-to-linear selectivity and $93 \%$ ee, but the $N$-allylated product $\mathbf{5 n}$ was isolated in a modest $53 \%$ yield due a competing $O$-allylation process (entry 10 ). The selectivity for $N$ - versus $O$-allylation did not improve when reactions were conducted at room temperature (entry 11). This reaction formed product $\mathbf{5 n}$ in $75 \%$ yield with high branched-to-linear selectivity (95:5), $N: O$ selectivity $(90: 10)$, and enantioselectivity (96\%) when conducted at room temperature in the presence of $2 \mathrm{~mol} \%$ of the ortho-OMe catalyst $\mathbf{2 b}$ (entry 12).

\section{Synthetic Utility of $\boldsymbol{N}$-Allyl Benzimidazoles}

Chiral benzimidazoles and the related benzimidazolones, which can be generated by oxidation of benzimidazoles, exhibit a diverse array of biological activity. Within these product classes chiral $\alpha$-benzimidazolyl alcohols, $\alpha$-benzimidazolyl acids, $\alpha$-benzimidazolyl amides, $\beta$ benzimidazolyl alcohols, $\beta$-benzimidazolyl acids, and $\beta$-benzimidazolyl amides are heterocyclic substructures (Figure 2) present in compounds studied as vanilloid recptor 1(VR1) inhibitors, ${ }^{57,58}$ integrin antagonists, ${ }^{59}$ Farnesoid-X-receptor (FXR) agonists, ${ }^{60}$ G-protein coupled receptor (GPCR) MrgX1 antagonists, ${ }^{61}$ and Kinesin Spindle Protein (KSP) inhibitors. ${ }^{62}$ Related benzimidazolones have been studied as vasopressin (AVP) receptor antagonists ${ }^{63}$ and Chymase inhibitors. ${ }^{64}$

Enantioenriched $\alpha$-benzimidazolyl alcohol and $\alpha$-benzimidazolyl acid derivatives have been synthesized by a sequence including the coupling of ortho-nitroaryl halides or 1,2dihalobenzenes with chiral amino alcohol and amino acid derivatives to generate orthonitroanilines or 1,2-benzenediamines. ${ }^{65,66}$ These intermediates are readily converted to $\alpha$ benzimidazolyl alcohol and $\alpha$-benzimidazolyl acid derivatives by reduction, in the case of ortho-nitroanilines to form a 1,2-benzenediamine, and condensation with a formic acid equivalent. These coupling strategies are practical methods to synthesize chiral, non-racemic benzimidazoles when the intermediate 1,2-benzenediamine is generated from an amino acid or an amino alcohol derived from naturally occurring, enantioenriched amino acids. However, these approaches require longer synthetic sequences when the intermediate 1,2benzenediamine is to be derived from unnatural $\alpha$-amino acids, $\beta$-amino acids, or the corresponding amino alcohols. 
Our iridium-catalyzed synthesis of enantiomerically enriched benzimidazoles can overcome these limitations because a variety of allylic carbonates are suitable electrophiles in the allylic substitution reaction. Thus, we investigated the transformation of our chiral $N$-allylated benzimidazole products to the chiral, non-racemic $\alpha$ - and $\beta$-benzimidazolyl alcohols (Scheme 2 ), which could be used to synthesize the corresponding carboxylic acid and amide derivatives. Ozonolysis of $N$-allyl benzimidazoles $\mathbf{5 a}$ and $\mathbf{5 h}$, followed by reduction of the resulting ozonides with $\mathrm{NaBH}_{4}$, formed $(S)$-2-(1H-benzo[ $d$ ] imidazol-1-yl)-2-phenylethanol $\mathbf{8 a}^{67}$ and $(S)$-2-(1H-benzo[d]imidazol-1-yl)pentan-1-ol $\mathbf{8 b}$ in $84 \%$ and $93 \%$ yield, respectively (eq 1 ). The sequence of oxidation and reduction occurs with full retention of the enantiomeric excess of the starting $N$-allylated benzimidazoles. Hydroboration of $N$-allyl benzimidazoles $\mathbf{5 a}$ and $\mathbf{5 h}$, followed by oxidation of the resulting alkylborane in the presence of basic hydrogen peroxide gave $(R)-3$-( $1 H$-benzo[ $d]$ imidazol-1-yl)-3-phenylpropan-1-ol 9a and $(S)-3-(1 H$ benzo[ $d]$ imidazol-1-yl)hexan-1-ol $9 b$ in $85 \%$ and $91 \%$ yield, respectively (eq 2). Furthermore, $\beta$-benzimidazolyl acids, such as the integrin antagonist 10,59 are readily synthesized by oxidation of the optically active $\beta$-benzimidazolyl alcohol in the presence of iodobenzene diacetate, TEMPO, and sodium bicarbonate (eq 3).

\section{Enantioselective $\mathbf{N}$-Allylation of Imidazole Nucleophiles}

$\mathrm{N}$-allylation reactions between imidazole nucleophiles and allylic electrophiles are known to occur in the presence of $\mathrm{Pd}(0)$ catalysts. ${ }^{68-70}$ However, enantioselective $N$-allylations of imidazole nucleophiles catalyzed by metal complexes that generate branched substitution products from the linear allylic esters have not been reported. Thus, we sought conditions to conduct the enantioselective allylation of imidazoles with the metallacylic iridium catalyst. The reaction of methyl cinnamyl carbonate with imidazole in the presence of $2 \mathrm{~mol} \%$ of the parent catalyst 2a occurred with high branched-to-linear selectivity and enantioselectivity, but gave product 12a in a moderate $76 \%$ yield (Table 4 , entry 1 ). The lower yield for the allylation of imidazole with methyl cinnamyl carbonate than for the allylation of benzimidazole (compare Table 2, entry 1 with Table 4, entry 1) resulted from partial isomerization of the $N$-allyl imidazole product 12a to the corresponding achiral enamine. However, the reaction of imidazole with methyl cinnamyl carbonate in the presence of $2 \mathrm{~mol} \%$ ortho-OMe catalyst $\mathbf{2 b}$ occurred without isomerization to the enamine (entry 2). This reaction formed product 12a in $87 \%$ yield with excellent branched-to-linear selectivity and enantioselectivity. Based on these results, catalyst $\mathbf{2 b}$ was chosen for further studies on the allylation of imidazole nucleophiles.

4,5-Diphenylimidazole, 2-phenylimidazole, and 4-phenylimidazole reacted with allylic carbonates in the presence of catalyst $\mathbf{2 b}$ to form $N$-allylation products. The reaction of 4,5diphenylimidazole with methyl cinnamyl carbonate formed product $\mathbf{1 2 b}$ in good yield with high selectivities (entry 3). The reaction of 2-phenylimidazole with methyl cinnamyl carbonate occurred with high enantioselectivity, but the yield and regioselectivity for the formation of product 12c were lower than those of the reactions of other imidazole nucleophiles (entry 4). The reaction of 4-phenyl imidazole occurred with nearly complete branched-to-linear selectivity to form N1-allylated imidazole 12d in 75\% isolated yield with $98 \%$ ee. Moreover, the reaction of this unsymmetrical imidazole with methyl cinnamyl carbonate occurred with good N1:N3 selectivity (83:17, entry 5).

\section{Formal Synthesis of a JNK3 Inhibitor}

The bicyclic bisarylimidazole 16 is a c-jun N-terminal kinase 3 (JNK3) inhibitor that was originally synthesized in $6 \%$ overall yield in 14 linear steps. ${ }^{48}$ Bergman, Ellman, and coworkers subsequently reported an improved synthesis of $\mathbf{1 6}$ in $13 \%$ overall yield and 11 linear steps (Figure 3$)^{49}$ using a rhodium-catalyzed C-H bond functionalization of the 1-(1-(tertbutyldiphenylsilyloxy)but-3-en-2-yl)-4-(4-fluorophenyl)- $1 H$-imidazole 18. Imidazole 18, the 
substrate for the rhodium-catalyzed $\mathrm{C}-\mathrm{H}$ bond functionalization to form the key bicyclic imidazole 17, was synthesized from 2-(tert-butyldimethylsilyloxy)acetaldehyde and $\left(S_{S}\right)$-tertbutanesulfinamide in 53\% yield over 5 steps. Our ability to conduct iridium-catalyzed allylations at the $\mathrm{N} 1$ position of an unsymmetrical 4-arylimidazole selectively led us to study this process as a simplified route to compound $\mathbf{1 8}$. After optimization of conditions, we found that the reaction of (E)-4-(tert-butyldiphenylsilyloxy)but-2-enyl methyl carbonate 19 with 4(4-fluorophenyl)- $1 \mathrm{H}$-imidazole 11e at room temperature in the presence of $4 \mathrm{~mol} \%$ of ortho$\mathrm{MeO}$ catalyst $\mathbf{2 b}$ occurred to high conversion with nearly complete branched-to-linear selectivity and useful N1:N3 selectivity (Scheme 3). The key $N$-allyl imidazole 18 was isolated from this reaction in 64\% yield with $91 \%$ ee. This reaction is a more direct approach to $\mathbf{1 8}$ than the previously reported 5 -step sequence and occurs in slightly higher yield. Rhodium-catalyzed cyclization of 18 gave bicyclic imidazole 17 in 63\% yield with 88\% ee. Bergman, Ellman, and co-workers have develop efficient conditions to synthesize the JNK3 inhibitor $\mathbf{1 6}$ from compound 17 in $49 \%$ yield over 5 steps.

\section{Enantioselective $\mathbf{N}$-Allylation of Purine Nucleophiles}

Having developed conditions for the enantioselective allylation of benzimidazoles and imidazoles, we tested these procedures for the more complex, but related, $N$-allylation of purines (Scheme 4). Such reactions would create a rapid route to a variety of chiral non-natural nucleotides, a class of compounds that have been widely studied as potential antiviral drugs. ${ }^{50-53}$ However, the $N$-allylation of these reagents is complicated by the potential that allylation could occur at N9 or N7 and that it could occur at the exocyclic nitrogen of adenine or the guanine surrogate, 2-amino-6-chloropurine.

Our effort to develop the allylation of purines initially focused on reactions of 6-chloropurine 20a with a variety of allylic carbonates in the presence of the parent catalyst 2a (Table 5). The allylation of 6-chloropurine with methyl cinnamyl carbonate 3a in the presence of $2 \mathrm{~mol} \%$ 2a occurred with incomplete conversion of 3a, but with excellent selectivities (entry 1). The reaction of 6-chloropurine with 3a did, however, occur to high conversion with high branchedto-linear ratio (21a:22a $=93: 7)$ in the presence of $4 \mathrm{~mol} \%$ of $\mathbf{2 a}$ as catalyst, and the N9branched product was isolated in $83 \%$ yield with $93 \%$ ee (entry 2). Furthermore, the N9:N7 selectivity for this reaction was $94: 6 .{ }^{71}$ Although purine nucleophiles are known to react preferentially at the N9-position, the observed N9:N7 selectivity for iridium-catalyzed allylic substitution with purine nucleophiles is striking when compared to analogous enantioselective palladium-catalyzed allylic substitution reactions that often result in N9:N7 selectivities of less than $9: 1 .^{13-15}$

Similar yields of the N9 allylation products 21 and levels of regio- and enantioselectivity were observed for the reactions of 6-chloropurine with a series of cinnamyl carbonates (entries 3-6). 72 With few exceptions, the N9:N7 selectivities were >93:7, the N9 branched-to-linear ratios were $>90: 10$, and the N9 substitution products 21 were isolated in $>75 \%$ yield with $>90 \%$ ee. One exception to these trends was the reaction of 6-chloropurine with methyl orthomethoxycinnamyl carbonate $3 \mathbf{3}$, which formed the $N$-allylated purine product $\mathbf{2 1 f}$ with moderate enantioselectivity in the presence of either catalyst $\mathbf{2 a}$ or catalyst $\mathbf{2 b}$ (entries 7 and $8, \mathbf{2 a} \rightarrow 78 \%$ ee, $\mathbf{2} \mathbf{b} \rightarrow 81 \%$ ee). The reaction of 6-chloropurine with aliphatic carbonate $3 \mathbf{k}$ in the presence of $4 \mathrm{~mol} \%$ 2a occurred with poor N9:N7 selectivity (74:26, entry 9). However, the same reaction conducted with $4 \mathrm{~mol} \% \mathbf{2 b}$ as the catalyst occurred with high regio- and enantioselectivity (N9:N7 = 93:7, entry 10). The difference in N9:N7 selectivity for the reaction of 6-chloropurine with $3 \mathbf{k}$ in presence of parent catalyst $\mathbf{2 a}$ and ortho-OMe catalyst $\mathbf{2 b}$ is probably due to a faster decomposition of catalyst $\mathbf{2 a}$ than of catalyst $\mathbf{2 b}$. The relative rates of catalyst decomposition are discussed in greater detail later in this paper. 
Several other purines underwent the allylation process in high yields and with high selectivities (Table 6). For example, reactions of 6-(methylthio)purine 20b and adenine 20c with methyl cinnamyl carbonate occurred to form products $21 \mathbf{h}$ and $21 \mathbf{i}$ with high N9:N7 and N9 branchedto-linear selectivities (entries 1 and 2). From these reactions, the branched allylated purine derivatives $\mathbf{2 1} \mathbf{h}$ and $\mathbf{2 1 i}$ were isolated in high yields with high enantioselectivities. The reaction of adenine conducted with a lower 2 mol \% loading of parent catalyst 2a occurred with a similar yield and selectivity for formation of $\mathbf{2 1 i}$ as the reaction with $4 \mathrm{~mol} \% \mathbf{2 a}$ (entry 3 ). In contrast, the allylations of bis-Boc-adenine $20 \mathrm{~d}$ and 2-amino-6-chloropurine 20e, a guanine equivalent, with methyl cinnamyl carbonate occurred with higher selectivities when conducted with ortho-OMe catalyst $\mathbf{2 b}$ than with the parent catalyst $\mathbf{2 a}$. The reaction of bis-Boc-adenine $\mathbf{2 0 d}$ with methyl cinnamyl carbonate to form product $\mathbf{2 1} \mathbf{j}$ proceeded to low conversion (entry 4 ) in the presence of 2 mol \% 2a, but occurred to high conversion with high N9:N7 selectivity, branched-to-linear selectivity, and enantioselectivity when conducted in the presence of $2 \mathrm{~mol}$ $\% \mathbf{2 b}$ (entry 5). Likewise, the reaction of 2-amino-6-chloropurine 20e with methyl cinnamyl carbonate occurred with modest N9:N7 selectivity (82:18, entry 6) in the presence of $2 \mathrm{~mol} \%$ 2a, but occurred with excellent N9:N7 selectivity when conducted in the presence of 2 mol $\% \mathbf{2 b}$ (entry 7).

\section{Application of the Enantioselective $\mathbf{N}$-Allylation of Purine Nucleophiles}

(9H-Purin-9-yl)alcohol cores are key substructures of the commercial antivirals adefovir and tenofovir, which are adenine analogues (Figure 4). Adefovir is FDA approved for treatment of hepatitis B infections, while tenofovir is FDA approved for treatment of HIV and hepatitis B infections. ${ }^{73-76}$ Analogues of current antiviral compounds are important for addressing the spread of viral resistance. Thus, we sought to illustrate how chiral $N$-allylated adenine derivatives could be converted to $\alpha$-adeninyl alcohols and $\beta$-adeninyl alcohols, which are optically active analogues of the anti-retrovirals adefovir and tenofovir (Scheme 5).

Ozonolysis of bis-BOC-protected adenine derivatives $\mathbf{2 1} \mathbf{j}$ and $\mathbf{2 1 1}$, followed by reduction of the resulting ozonides with $\mathrm{NaBH}_{4}$, formed bis-Boc-protected ( $S$ )-2-(6-amino-9H-purin-9yl)-2-phenylethanol 25a and bis-Boc-protected (S)-2-(6-amino-9H-purin-9-yl)pentan-1-ol 25b in $89 \%$ and $88 \%$ yield, respectively, without erosion of enantiomeric purity (Equation 1). Standard procedures for hydroboration and oxidation gave complex product mixtures from reactions of bis-BOC-protected adenine derivatives $\mathbf{2 1} \mathbf{j}$ and $\mathbf{2 1 1} .{ }^{77,78}$ However, hydroboration of the monomethoxytrityl(MMTr)-protected adenine derivatives 26a and 26b, followed by oxidation of the resulting alkylboranes in the presence of basic hydrogen peroxide gave $\mathrm{MMTr}$ protected $(R)-3$-(6-amino-9H-purin-9-yl)-3-phenylpropan-1-ol) 27a and MMTr-protected (S)-3-(6-amino-9H-purin-9-yl)hexan-1-ol 27b in $82 \%$ and $77 \%$ yield (Equation 2). Thus, a combination of iridium-catalyzed allylation, followed by ozonolysis and reduction or hydroboration and oxidation provides a new route to chiral, non-racemic derivatives of adenine that are related to FDA approved reverse transcriptase inhibitors.

\section{Competition between Azole and Amine Nucleophiles}

After developing methods for the regio- and enantioselective $\mathrm{N}$-allylation of benzimidazoles, imidazoles, and purines, we conducted a series of competition experiments to develop an understanding of the relative nucleophilicities of these heterocycles and other common nitrogen nucleophiles toward iridium-catalyzed allylic substitution reactions (Scheme 6). These experiments were designed to provide a basis to rationalize the high yields for reactions of the imidazole, benzimidazole, and purine reagents, which are typically weaker nucleophiles than amines, toward metal-catalyzed allylic substitution reactions. Mayr's scale of nucleophilicity for nitrogen nucleophiles provides benchmark reactivities of benzylamine, aniline, and imidazole with $S$-methyldibenzothiophenium ion and a variety of benzhydrylium ions as electrophiles. ${ }^{79,80}$ The nucleophilicity and nucleophile-specific slope parameters for these 
nucleophiles show that benzylamine reacts twice as fast as aniline and 20 times faster than imidazole with the activated electrophiles studied by Mayr and co-workers. We conducted competition experiments between imidazole and benzylamine, aniline, benzimidazole, and bisBOC-adenine to determine whether this trend in nucleophilicity, based on reactions of nitrogen nucleophiles with $S$-methyldibenzothiophenium ion and benzhydrylium ions as electrophiles, holds for iridium-catalyzed $N$-allylation reactions.

Reactions of imidazole ( 2 equivalents) and either benzylamine, aniline, benzimidazole, or bisBoc-adenine ( 2 equivalents) with methyl cinnamyl carbonate 3a (1.0 equivalent) were performed in the presence of $\mathrm{K}_{3} \mathrm{PO}_{4}(1.0$ equivalent) and $4 \mathrm{~mol} \% \mathbf{2} \mathbf{b}$. The reaction of 3a with benzylamine and imidazole gave the $N$-allylamine and imidazole products 28 and 11 in a 74:26 ratio (Equation 1). Thus, benzylamine reacts faster than imidazole in this iridiumcatalyzed process, as expected, but the 3:1 ratio of relative rates was much smaller than the 20:1 ratio that would be expected based on Mayr's nucleophile parameters for benzyl amine $(\mathrm{N}=13.46, s=0.62)$ and imidazole $(\mathrm{N}=10.41, s=0.70)$. The discrepancy is best explained by a contribution from the reaction of imidazolate, rather than imidazole. The imidazolate would be generated by deprotonation of the heterocycle by $\mathrm{K}_{3} \mathrm{PO}_{4}$ or the counterion of the iridium-allyl intermediate, which could be the methyl carbonate or methoxide after decarboxylation of the carbonate. If so, then the observed selectivity would result from a competition between benzylamine and the imidazolate or, more precisely, between benzylamine and an equilibrium mixture of the neutral imidazole and the anionic imidazolate.

The competition experiment between aniline and imidazole provides further evidence to support this hypothesis. $N$-allyl aniline and imidazole products 29 and 11a were formed in a 46:54 ratio favoring the imidazole product 11a (Equation 2). This ratio is, again, much smaller than the 10:1 ratio of rates for aniline versus imidazole that would be expected from the nucleophile parameters for these two nucleophiles $(\mathrm{N}=12.64, s=0.68$ for aniline and $\mathrm{N}=$ $10.41, s=0.70$ for imidazole). Furthermore, competition experiments between imidazole and either benzimidazole or bis-Boc-adenine favor the formation of the benzimidazole product 5a (Equation 3, 11a:5a = 29:71) or the bis-Boc-adenine product $\mathbf{2 1} \mathbf{j}$ (Equation 4, 11a:21j = 15:85), resulting from allylation of the more acidic of the two nucleophiles in each case. The combination of these results suggests that imidazole, benzimidazole and adenine nucleophiles undergo facile iridium-catalyzed $N$-allylation reactions because of the contributions from reaction of the deprotonated species. The competition experiments also show that an increased acidity of the heterocycle, rather than increased basicity, leads to faster rates for allylation of these heterocycles (10a: $p \mathrm{~K}_{\mathrm{a}}=18.6$; 5a: $p \mathrm{~K}_{\mathrm{a}}=16.4 ; \mathbf{2 0 d}: p \mathrm{~K}_{\mathrm{a}} \approx 15$ in DMSO). ${ }^{81}$

The results from the competition experiments displayed in Scheme 6 suggest that imidazolate, benzimidazolate, and adeninate anions are the form of the heterocycles that undergo the $\mathrm{N}$ allylation reactions. To test whether the methyl carbonate or methoxide anion formed upon generation of the intermediate allyliridium complex or exogenous $\mathrm{K}_{3} \mathrm{PO}_{4}$ acted as the base primarily responsible for the formation of the deprotonated heterocycle species, we studied the reaction of benzimidazole with methyl cinnamyl carbonate catalyzed by 4 mol \% 2a or $2 \mathrm{~mol}$ $\% 2 \mathbf{b}$ in the absence of $\mathrm{K}_{3} \mathrm{PO}_{4}$ at room temperature and at $50{ }^{\circ} \mathrm{C}$ (Scheme 7).

Two sets of data lead to several conclusions about the relative importance of the potassium phosphate and the counterions of the allyl complex as base. First, the reaction of $\mathbf{3 a}$ with $4 \mathbf{a}$ in the presence of $4 \mathrm{~mol} \%$ of the parent catalyst $2 \mathrm{a}$ was $68 \%$ complete after $5 \mathrm{~h}$ at room temperature, while the same reaction conducted at $50{ }^{\circ} \mathrm{C}$ was only $52 \%$ complete after $5 \mathrm{~h}$ (eq 1). The reaction of $\mathbf{3 a}$ with $\mathbf{4 a}$ catalyzed by $2 \mathrm{~mol} \%$ of the ortho-OMe catalyst $\mathbf{2 b}$ was $85 \%$ complete after $4 \mathrm{~h}$ at room temperature, while the same reaction conducted at $50{ }^{\circ} \mathrm{C}$ was $77 \%$ complete after $4 \mathrm{~h}$ (eq 2). Because these reactions proceeded in the absence of added $\mathrm{K}_{3} \mathrm{PO}_{4}$, we conclude that the methyl carbonate or methoxide generated in situ can serve as the base to 
form the benzimidazolate nucleophile and that base-free allylations of heterocyclic nucleophiles can be developed. Because higher conversions were observed for reactions conducted in the absence of $\mathrm{K}_{3} \mathrm{PO}_{4}$ at room temperature than from those at $50^{\circ} \mathrm{C}$, we conclude that increasing catalyst deactivation occurs during the reactions with increasing temperature.

Second, competition experiments that are analogous to those shown in Scheme 6, but conducted in the absence of $\mathrm{K}_{3} \mathrm{PO}_{4}$, generate product ratios that contain more of the species derived from the less acidic nitrogen nucleophile. ${ }^{82}$ This observation, along with the observation of reaction in the absence of exogenous base suggest that both the methyl carbonate (or methoxide) generated in situ and $\mathrm{K}_{3} \mathrm{PO}_{4}$ contribute to the formation of benzimidazolate nucleophile. Although we are cognizant of the limited solubility of $\mathrm{K}_{3} \mathrm{PO}_{4}$ in THF solvent and the close proximity of the counterions to the allyliridium intermediate, we suggest that reactions conducted with added $\mathrm{K}_{3} \mathrm{PO}_{4}$ contain a higher concentration of benzimidazolate anion than reactions conducted without added $\mathrm{K}_{3} \mathrm{PO}_{4}$. An increase in the concentration of benzimidazolate anion would increase the rate of the $N$-allylation of nucleophiles containing more acidic N-H bonds, and this prediction is consistent with the larger amounts of product derived from the more acidic nitrogen nucleophiles in reactions conducted with added $\mathrm{K}_{3} \mathrm{PO}_{4}$.

\section{Studies of the Relative Activity and Stability of Catalysts $\mathbf{2 a}$ and $\mathbf{2 b}$}

Kinetic studies of the reactions of benzimidazole with methyl cinnamyl carbonate catalyzed by bis-phosphoramidite complexes $\left[\operatorname{Ir}(\mathrm{COD})\left(\kappa^{2}-\mathbf{L} \mathbf{1}\right)(\mathbf{L 1})\right](\mathbf{1})$ and $\left[\operatorname{Ir}(\mathrm{COD})\left(\kappa^{2}-\mathbf{L} 2\right)(\mathbf{L 2})\right]$ (30) were conducted to gauge the effect of substituents on the phosphoramidite ligand on catalyst stability and activity in the presence and absence of $\mathrm{K}_{3} \mathrm{PO}_{4}$. A comparison of reactions in the presence and absence of $\mathrm{K}_{3} \mathrm{PO}_{4}$ catalyzed by the combination of $[\mathrm{Ir}(\mathrm{COD}) \mathrm{Cl}]_{2}$ (to bind the $\kappa^{1}$-phosphoramidite after dissociation) and complex $\mathbf{1}$ or $\mathbf{3 0}$ is shown if Figure 5. As previously observed during the development of conditions for the reaction of benzimidazole with methyl cinnamyl carbonate (see Table 1 , entry 1 ), the reactions catalyzed by bisphosphoramidite complexes $\mathbf{1}$ and $\mathbf{3 0}$ occurred to low conversions in the absence of $\mathrm{K}_{3} \mathrm{PO}_{4}$. However, analogous reactions at room temperature occurred to high conversions when conducted in the presence of 1.0 equivalent of $\mathrm{K}_{3} \mathrm{PO}_{4}$. These data show that deactivation of either the metallacyclic catalysts $\mathbf{1}$ and $\mathbf{3 0}$ or the $[\operatorname{Ir}(\mathrm{COD}) \mathrm{Cl}]_{2}$ occurred rapidly in the absence of exogenous base. Furthermore, these data suggest that substituents on the arylethyl group of the phosphoramidite ligand have minimal impact on the stability and activity of metallacyclic bis-phosphoramidite catalysts $\mathbf{1}$ and $\mathbf{3 0}$.

In contrast to the reactions catalyzed by bis-phosphoramidite complexes $\mathbf{1}$ and $\mathbf{3 0}$, the reactions catalyzed by metallacyclic ethylene adducts $\left[\operatorname{Ir}(\mathrm{COD})\left(\kappa^{2}-\mathbf{L 1}\right)(\right.$ ethylene $\left.)\right](\mathbf{2 a})$ and $[\operatorname{Ir}(\mathrm{COD})$ $\left(\kappa^{2}\right.$-L2)(ethylene)] (2b) (Figure 6) were significantly affected by the substituents on the arylethyl group of the phosphoramidite ligand. The reaction of methyl cinnamyl carbonate with benzimidazole in the presence of parent catalyst $\mathbf{2 a}$ without added $\mathrm{K}_{3} \mathrm{PO}_{4}$ occurred to modest conversion, but the same reaction catalyzed by ortho-OMe catalyst $\mathbf{2 b}$ occurred to nearly complete conversion. This result implies that the metallacyclic iridium complex $\mathbf{2 b}$ generated from the ortho-anisyl phosphoramidite ligand $\mathbf{L} \mathbf{2}$ is more stable toward decomposition than the metallacyclic iridium complex 2a generated from the parent phosphoramidite L1. In contrast, the kinetic profile of the reactions catalyzed by complexes $\mathbf{2 a}$ and $\mathbf{2 b}$ are similar to each other in the presence of added $\mathrm{K}_{3} \mathrm{PO}_{4}$. This result implies that the phosphate base prevents decomposition of the catalyst and that the rates of the sets of reactions within the catalytic cycle involving the species generated from the ethylene adducts $\mathbf{2 a}$ and $\mathbf{2} \mathbf{b}$ are similar to each other. The latter conclusion contrasts a previous claim that the ortho-anisyl phosphoramidite ligand L2 generates a more active metallacyclic iridium catalyst than does phosphoramidite ligand L1. $^{32}$ 
We propose that the metallacyclic catalysts undergo decomposition by protonation of the metallacyclic unit to form an inactive acyclic species. Metallacyclic iridium complexes 2a and $\mathbf{2 b}$ are formed from the four-coordinate iridium complexes $\mathbf{3 1} \mathbf{a}$ and $\mathbf{3 1} \mathbf{b}$ and ethylene in the presence of an amine base, and opening of the metallacycle occurs upon addition of a protic acid, such as acetic acid or excess amine hydrochloride (Scheme 8). ${ }^{17}$ Thus, metallacyclic iridium catalysts $\mathbf{2 a}$ and $\mathbf{2 b}$ would be expected to be stable during allylic substitution reactions of basic nitrogen nucleophiles but to undergo ring opening as a side reaction during allylic substitution reactions of the acidic nitrogen nucleophiles studied in this work.

To assess this proposal for the mechanism of decomposition of the iridium metallacycles in the presence of the imidazole nucleophiles, we studied the stoichiometric reactions of catalysts $2 \mathrm{a}$ and $\mathbf{2 b}$ with excess benzimidazole $\left(p \mathrm{~K}_{\mathrm{a}}=16.4, \mathrm{DMSO}\right)$ and bis-BOC-adenine $\left(p \mathrm{~K}_{\mathrm{a}} \approx 15\right.$, DMSO). Consistent with our conclusion about the relative stabilities of catalysts $\mathbf{2 a}$ and $\mathbf{2} \mathbf{b}$, parent catalyst 2a reacted with the two azoles more rapidly than did the ortho-OMe catalyst 2b. The half-life of catalyst $2 \mathbf{a}$ in $\mathrm{THF}$ at $50{ }^{\circ} \mathrm{C}$ in the presence of 25 equiv of benzimidazole was approximately $60 \mathrm{~min}$, while the half-life of catalyst $2 \mathrm{~b}$ was greater than $4 \mathrm{~h}$ under identical conditions. Furthermore, the half-life of catalyst 2a in the presence of 25 equivalents of bisBOC adenine was less than $20 \mathrm{~min}$, while the half-life of catalyst $\mathbf{2 b}$ was approximately 40 $\min$. Analogous reactions of $\mathbf{2 a}$ and $\mathbf{2} \mathbf{b}$ with $N$-methyl benzimidazole and 9-methyl-bis-BOCadenine resulted in minimal decomposition of $\mathbf{2 a}$ or $\mathbf{2} \mathbf{b}$.

The stoichiometric reaction of parent catalyst $\mathbf{2 a}$ with excess benzimidazole was studied in further depth to develop a more detailed understanding of the reactions leading to catalyst decomposition (Scheme 9). Three major new species were observed by ${ }^{31} \mathrm{P}\left\{{ }^{1} \mathrm{H}\right\}$ NMR spectroscopy from this reaction. Two sets of doublets that correspond to $\left[\operatorname{Ir}(\mathrm{COD})\left(\kappa^{2}-\mathbf{L 1}\right)\right.$ (L1)] (1) were observed at $153.5 \mathrm{ppm}(J=47 \mathrm{~Hz})$ and $128.6 \mathrm{ppm}(J=47 \mathrm{~Hz})$, and a singlet corresponding to the free phosphoramidite ligand $\mathbf{L} \mathbf{1}$ was observed at $151.2 \mathrm{ppm}$. In addition, a singlet at $120.0 \mathrm{ppm}$, which we propose to correspond to $[\operatorname{Ir}(\mathrm{COD})(\mathbf{L 1})$ (benzimidazolate)] (32), was observed transiently. Attempts to independently synthesize complex $\mathbf{3 2}$ from the reaction of $[\operatorname{Ir}(\mathrm{COD})(\mathbf{L 1}) \mathrm{Cl}]($ 31a) with sodium benzimidazolate led to rapid formation of free phosphoramidite ligand $\mathbf{L 1}$ and the known complex $\left[\operatorname{Ir}(\mathrm{COD})(\text { benzimidazolate) }]_{3}\right.$ as a yellow precipitate (Scheme 10). ${ }^{83}$

Based on these data, we propose that catalyst $\mathbf{2 a}$ reacts with benzimidazole to form benzimidazolate complex $\mathbf{3 2}$ as a transient intermediate, either by direct protonation of the metallacycle or by oxidative addition of the azole N-H bond, ${ }^{84}$ followed by reductive elimination to form a C-H bond. Complex $\mathbf{3 2}$ decomposes to form free phosphormidite $\mathbf{L} \mathbf{1}$ and $[\operatorname{Ir}(\mathrm{COD}) \text { (benzimidazolate) }]_{3}$. The free phosphoramidite ligand $\mathbf{L} \mathbf{1}$ then reacts with ethylene adduct $2 \mathbf{a}$ to form $\left[\operatorname{Ir}(\mathrm{COD})\left(\kappa^{2}-\mathbf{L} \mathbf{1}\right)(\mathbf{L 1})\right](\mathbf{1})$, which is known to catalyze the allylic substitution reaction with slow rates in the absence of an additive to sequester the second phosphoramidite ligand. ${ }^{38}$

The ortho-OMe catalyst $\mathbf{2 b}$ is more stable toward benzimidazole than the parent catalyst $\mathbf{2 a}$. After $4 \mathrm{~h}$ at $50{ }^{\circ} \mathrm{C}$, the only decomposition product (ca. 30\%) observed by ${ }^{31} \mathrm{P}\left\{{ }^{1} \mathrm{H}\right\} \mathrm{NMR}$ spectroscopy from the stoichiometric reaction of $\mathbf{2 b}$ with excess benzimidazole was the free phosphoramidite ligand $\mathbf{L} 2$ at $155.4 \mathrm{ppm}$. $\left[\operatorname{Ir}(\mathrm{COD})\left(\kappa^{2}-\mathbf{L 2}\right)(\mathbf{L 2})\right](\mathbf{3 0})$, the ortho-anisyl analogue of $\left[\operatorname{Ir}(\mathrm{COD})\left(\kappa^{2}-\mathbf{L 1}\right)(\mathbf{L 1})\right](\mathbf{1})$, was not observed in the reaction of $\mathbf{2 b}$ with benzimidazole. This result implies that the increased stability of ortho-OMe catalyst $\mathbf{2 b}$, relative to parent the catalyst $2 \mathbf{a}$, results from two factors. First, the rate of ring opening of the metallacycle in ortho-OMe catalyst $\mathbf{2 b}$ is slower than that for parent catalyst $\mathbf{2 a}$. Second, ortho-OMe catalyst $\mathbf{2} \mathbf{b}$ does not readily react with free phosphoramidite ligand $\mathbf{L} \mathbf{2}$ to form the less active catalyst $\left[\operatorname{Ir}(\mathrm{COD})\left(\kappa^{2}-\mathbf{L} 2\right)(\mathbf{L 2})\right](\mathbf{3 0})$. These factors result in a concentration of $\mathbf{2 b}$ that is greater than that of $\mathbf{2 a}$ in catalytic reactions of azole nucleophiles with allylic carbonates 
in the absence of $\mathrm{K}_{3} \mathrm{PO}_{4}$. Furthermore, these results are consistent with rates of reactions of benzimidazole with methyl cinnamyl carbonate in the absence of $\mathrm{K}_{3} \mathrm{PO}_{4}$ base that are faster when catalyzed by ortho-OMe complex $\mathbf{2 b}$ than when catalyzed by parent complex $\mathbf{2 a}$ (Figure $6)$.

\section{Base-Free $\mathbf{N}$-Allylation of Benzimidazole and Imidazole Nucleophiles}

The stability of catalyst $\mathbf{2 b}$ toward deactivation in the presence of benzimidazole led us to study reactions of benzimidazole and imidazole nucleophiles in the absence of added $\mathrm{K}_{3} \mathrm{PO}_{4}$ (Table 7). The room temperature reactions of methyl cinnamyl carbonate with benzimidazole, 2phenylbenzimidazole, and 2-chlorobenzimidazole in the presence of $2 \mathrm{~mol} \%$ of the orthoOMe catalyst $\mathbf{2 b}$ occurred to high conversions and formed products $\mathbf{5 a}, \mathbf{5 j}$, and $\mathbf{5 m}$ in high yields ( $>84 \%$ ) with high selectivities (branched-to-linear $>92: 8$ and $>97 \%$ ee) (entries 1-3). Imidazole nucleophiles, which contain a less acidic N-H bond than the benzimidazoles, also reacted selectively with $\mathbf{3 a}$ (entries 4 and 5). Products 12a and $\mathbf{1 2 b}$ were formed in greater than $86 \%$ yield with $>95: 5$ branched-to-linear selectivity and $>98 \%$ ee.

The instability of catalyst $\mathbf{2 b}$ to bis-BOC adenine in the absence of $\mathrm{K}_{3} \mathrm{PO}_{4}$ implied that basefree $\mathrm{N}$-allylations of purine nucleophiles would not occur to the same high conversions as were observed for reactions of the benzimidazoles and imdazoles. Indeed, the reaction of bis-Bocadenine with methyl cinnamyl carbonate occurred to only $63 \%$ conversion, and product $\mathbf{2 1 k}$ was isolated in only $49 \%$ yield (Scheme 11). Thus, base-free, iridium-catalyzed $N$-allylations of benzimidazole and imidazole nucleophiles with allylic carbonates occur in high yield and selectivity with catalyst $\mathbf{2 b}$, while allylations of purine nucleophiles should be conducted with added $\mathrm{K}_{3} \mathrm{PO}_{4}$ to prevent deactivation of metallacyclic iridium catalysts $\mathbf{2 a}$ and $\mathbf{2} \mathbf{b}$.

\section{Conclusions}

In summary, we have developed the first catalytic enantioselective allylation of benzimidazole, imidazole, and purine nucleophiles with achiral acyclic allylic electrophiles to form chiral $\mathrm{N}$ allylated azoles. These reactions are enabled by the use of single-component ethylene catalysts 2a and $\mathbf{2 b}$. Reactions with these single-component catalysts occur with less isomerization and with less iridium than those with previous metallacyclic iridium catalysts. The $N$-allylated benzimidazoles and purines generated from these reactions are readily converted to substructures, such as $\alpha$-benzimidazolyl alcohols, $\beta$-benzimidazolyl alcohols, $\beta$ benzimidazolyl acids, $\alpha$-purinyl alcohols, and $\beta$-purinyl alcohols, present in a variety of biologically important compounds. Furthermore, a formal synthesis of a JNK3 inhibitor demonstrates that iridium-catalyzed allylation provides rapid access to $N$-allylated imidazoles that can be transformed into enantiomerically enriched annulated products by intramolecular addition of an imidazole $\mathrm{C}(2)-\mathrm{H}$ bond across the pendant alkene. In addition, base-free $N$ allylation of benzimidazole and imidazole nucleophiles occurs readily in the presence of $\mathbf{2} \mathbf{b}$ as catalyst.

Competition experiments between azole nucleophiles and common amine nucleophiles helped elucidate the factors that lead to the ability to conduct the $N$-allylation of azole nucleophiles, even though they are much weaker nucleophiles than benzylamines, alkylamines, and arylamines in stoichiometric reactions with organic electrophiles. More specifically, the ratio of rates from competition reactions of amines versus azoles is much smaller than that for reaction of the two types of neutral nucleophiles toward organic electrophiles. Because this ratio of rates depended on the presence or absence of added base, we suggest that the deprotonated forms of imidazole, benzimidazole, and adenine nucleophiles react, at least in part, as the nucleophile for the iridium-catalyzed $N$-allylation reactions. This hypothesis also rationalizes the preferential reaction of the more acidic azoles in competition studies conducted in the presence of base. The same trend is not observed when comparing the rates of separate 
allylation reactions of the different classes of azoles because the more acidic heterocycles led to faster catalyst decomposition.

Kinetic studies of reactions catalyzed by metallacyclic complexes $\mathbf{2 a}$ and $\mathbf{2 b}$ show that the rates of reactions catalyzed by the parent catalyst $\mathbf{2 a}$ and the ortho-OMe-substituted catalyst $\mathbf{2 b}$ are similar, but that catalyst $\mathbf{2 b}$ is more stable to acidic benzimidazole, imidazole, and purine nucleophiles than is catalyst 2a. Stoichiometric reactions of the metallacyclic complexes 2a and $\mathbf{2 b}$ with azoles show that ring opening of the metallacycles occurs in the presence of the azoles to form $[\operatorname{Ir}(\mathrm{COD}) \text { (benzimidazolate) }]_{3}$ and free phosphoramidite ligand $\mathbf{L 1}$ or $\mathbf{L} \mathbf{2}$ and that ring opening of the metallacycle in the ortho-OMe-substituted complex $\mathbf{2 b}$ is slower than that of the metallacycle in parent complex 2a. In addition, complex 2a reacts with free ligand $\mathbf{L 1}$ to generate the less active catalyst $\left[\operatorname{Ir}(\mathrm{COD})\left(\kappa^{2}-\mathbf{L 1}\right)(\mathbf{L 1})\right](\mathbf{1})$. This process is not observed in stoichiometric reactions of complex $\mathbf{2} \mathbf{b}$ with azole nucleophiles, and the absence of this process provides further evidence of the improved stability of ortho-OMe-substituted catalyst 2b relative to parent catalyst 2a. Efforts to develop more robust iridium catalysts that will extend the method to additional azole nucleophiles and other acidic nitrogen nucleophiles are currently underway.

\section{Supplementary Material}

Refer to Web version on PubMed Central for supplementary material.

\section{Acknowledgments}

We thank the NIH for financial support of this work (NIH GM55382 to J.F.H. and GM84584 to L.M.S.) and JohnsonMatthey for gifts of $[\mathrm{Ir}(\mathrm{COD}) \mathrm{Cl}]_{2}$ and $\mathrm{IrCl}_{3}$. We thank Dr. Klaus Ditrich and BASF for a gift of both enantiomers of 1-(2-methoxyphenyl)ethylamine. We thank Mark Pouy and Dr. Dan Weix for experimental assistance and insightful discussions.

\section{References}

1. Lu Z, Ma S. Angew Chem Int Ed 2008;47:258-297.

2. Graening T, Schmalz HG. Angew Chem Int Ed 2003;42:2580-2584.

3. Trost BM. J Org Chem 2004;69:5813-5837. [PubMed: 15373468]

4. Trost BM, Crawley ML. Chem Rev 2003;103:2921-2944. [PubMed: 12914486]

5. Dai LX, Tu T, You SL, Deng WP, Hou XL. Acc Chem Res 2003;36:659-667. [PubMed: 12974649]

6. Agrofoglio LA, Gillaizeau I, Saito Y. Chem Rev 2003;103:1875-1916. [PubMed: 12744695]

7. Trost BM. Acc Chem Res 1996;29:355-364.

8. Trost BM, Van Vranken DL. Chem Rev 1996;96:395-422. [PubMed: 11848758]

9. Helmchen G, Dahnz A, Dubon P, Schelwies M, Weinhofen R. Chem Commun 2007:675-691.

10. Takeuchi R, Kezuka S. Synthesis 2006:3349-3366.

11. Pozharskii, AF.; Soldatenkov, AT.; Katritzky, AR. Heterocycles in Life and Society. Wiley; New York: 1997.

12. Katritzky, AR.; Pozharskii, AF. Handbook of Heterocyclic Chemistry. 2nd. Pergamon; Oxford: 2002.

13. Trost BM, Madsen R, Guile SG, Elia AEH. Angew Chem Int Ed Engl 1996;35:1569-1572.

14. Trost BM, Shi Z. J Am Chem Soc 1996;118:3037-3038.

15. Trost BM, Madsen R, Guile SD, Brown B. J Am Chem Soc 2000;122:5947-5956.

16. Trost BM, Dong G. J Am Chem Soc 2006;128:6054-6055. [PubMed: 16669672]

17. Spiess S, Welter C, Franck G, Taquet JP, Helmchen G. Angew Chem Int Ed 2008;47:7652-7655.

18. Bondzic BP, Farwick A, Liebich J, Eilbracht P. Org Biomol Chem 2008;6:3723-3731. [PubMed: 18843402]

19. Pouy MJ, Leitner A, Weix DJ, Ueno S, Hartwig JF. Org Lett 2007;9:3949-3952. [PubMed: 17725361]

20. Markovic D, Hartwig JF. J Am Chem Soc 2007;129:11680-11681. [PubMed: 17725356] 
21. Lee JH, Shin S, Kang J, Lee S. J Org Chem 2007;72:7443-7446. [PubMed: 17705538]

22. Spiess S, Berthold C, Weinhofen R, Helmchen G. Org Biomol Chem 2007;5:2357-2360. [PubMed: 17637953]

23. Yamashita Y, Gopalarathnam A, Hartwig JF. J Am Chem Soc 2007;129:7508-7509. [PubMed: 17523648]

24. Defieber C, Ariger MA, Moriel P, Carreira EM. Angew Chem Int Ed 2007;46:3139-3143.

25. Singh OV, Han H. Journal of the American Chemical Society 2007;129:774-775. [PubMed: 17243809]

26. Nemoto T, Sakamoto T, Matsumoto T, Hamada Y. Tetrahedron Lett 2006;47:8737-8740.

27. Shekhar S, Trantow B, Leitner A, Hartwig JF. J Am Chem Soc 2006;128:11770-11771. [PubMed: 16953612]

28. Polet D, Alexakis A, Tissot-Croset K, Corminboeuf C, Ditrich K. Chem Eur J 2006;12:3596-3609.

29. Leitner A, Shekhar S, Pouy MJ, Hartwig JF. J Am Chem Soc 2005;127:15506-15514. [PubMed: 16262414]

30. Welter C, Moreno RM, Streiff S, Helmchen G. Org Biomol Chem 2005;3:3266-3268. [PubMed: 16132087]

31. Weihofen R, Dahnz A, Tverskoy O, Helmchen G. Chem Commun 2005:3541-3543.

32. Polet D, Alexakis A. Org Lett 2005;7:1621-1624. [PubMed: 15816767]

33. Leitner A, Shu C, Hartwig JF. Org Lett 2005;7:1093-1096. [PubMed: 15760147]

34. Miyabe H, Matsumura A, Moriyama K, Takemoto Y. Org Lett 2004;6:4631-4634. [PubMed: 15548093]

35. Shu C, Leitner A, Hartwig JF. Angew Chem Int Ed 2004;43:4797-4800.

36. Tissot-Croset K, Polet D, Alexakis A. Angew Chem Int Ed 2004;43:2426-2428.

37. Welter C, Koch O, Lipowsky G, Helmchen G. Chem Commun 2004:896-897.

38. Kiener CA, Shu C, Incarvito C, Hartwig JF. J Am Chem Soc 125:2003. 14272-14273.

39. Lipowsky G, Helmchen G. Chem Commun 2004:116-117.

40. Ohmura T, Hartwig JF. J Am Chem Soc 2002;124:15164-15165. [PubMed: 12487578]

41. Weihofen R, Tverskoy O, Helmchen G. Angew Chem Int Ed 2006;45:5546-5549.

42. Gandelman M, Jacobsen EN. Angew Chem Int Ed 2005;44:2393-2397.

43. Evans PA, Lai KW, Zhang HR, Huffman JC. Chem Commun 2006:844-846.

44. Evans PA, Qin J, Robinson JE, Bazin B. Angew Chem Int Ed 2007;46:7417-7419.

45. Alamgir M, Black DSC, Kumar N. Top Heterocycl Chem 2007;9:87-118.

46. De Luca L. Curr Med Chem 2006;13:1-23. [PubMed: 16457636]

47. Legraverend M, Grierson DS. Bioorg Med Chem 2006;14:3987-4006. [PubMed: 16503144]

48. Graczyk PP, et al. Bioorg Med Chem Lett 2005;15:4666-4670. [PubMed: 16153829]

49. Rech JC, Yato M, Duckett D, Ember B, LoGrasso PV, Bergman RG, Ellman JA. J Am Chem Soc 2007;129:490-491. [PubMed: 17227002]

50. Simons, C. Nucleoside Mimetics Their Chemistry and Biological Properties. Gordon and Breach; Australia: 2001.

51. Song GY, Paul V, Choo H, Morrey J, Sidwell RW, Schinazi RF, Chu CK. J Med Chem 2001;44:39853993. [PubMed: 11689085]

52. Agrofoglio, LA.; Challand, SR. Acyclic, Carbocyclic and L-Nucleosides. Kluwer Academic; Dordrecht: 1998.

53. Anastasi C, Quelever G, Burlet S, Garino C, Souard F, Kraus JL. Curr Med Chem 2003;10:18251843. [PubMed: 12871107]

54. Neugnot B, Cintrat JC, Rousseau B. Tetrahedron 2004;60:3575-3579.

55. Higashino T, Sakaguchi S, Ishii Y. Org Lett 2000;2:4193-4195. [PubMed: 11150197]

56. Ueno S, Hartwig JF. Angew Chem Int Ed 2008;47:1928-1931.

57. Besidski Y, Kers I, Nylof M, Rotticci D, Slaitas A, Swensson M. PCT Int Appl. 2004 WO 04/100865 A2.

58. Besidski Y, Kers I, Nylof M, Slaitas A. PCT Int Appl. 2006 WO 06/033620 A1. 
59. Bloxham J, Borzillo GV, Collington EW, Sadiq S, Sambrook Smith CP, Waller CL, Wynne GM. PCT Int Appl. 2006 WO 06/053342 A2.

60. Benson GM, Bleicher K, Chucholowski A, Dehmlow H, Grether U, Kuhn B, Martin RE, Niesor EJ, Panday N, Richter H, Schuler F, Warot XM, Wright M, Yang M. PCT Int Appl. 2008 WO 08/000643 A1.

61. Olsson R, Knapp AE, Eskildsen J. PCT Int Appl. 2008 WO 08/052072 A2.

62. Shipps GW Jr, Ma Y, Lahue BR, Seghezzi W, Herbst R, Chuang C, Annis DA, Kirtley M. PCT Int Appl. 2008 WO 08/153701 A1.

63. Arndt T, Oost T, Lubisch W, Wernet W, Hornberger W, Unger L, Ruiz Caro J. PCT Int Appl. 2006 WO 08/025736 A1.

64. Abeywardane A, Cook BN, Delombaert S, Emmanuel MJ, Guo X, Kim JM, Hao MH, Lo HY, Man CC, Morwick T, Nemoto PA, Qian KC, Takahashi H, Taylor SJ. PCT Int Appl. 2008 WO 08/147697 A1.

65. Lee J, Doucette A, Wilson NS, Lord J. Tetrahedron Lett 2001;42:2635-2638.

66. Rivas FM, Giessert AJ, Diver ST. The Journal of Organic Chemistry 2002;67:1708-1711. [PubMed: 11871911]

67. The absolute configuration of $\mathbf{8 a}$ was assigned after conversion to the corresponding methyl ether. See the Supporting Information for additional details.

68. Saville-Stones EA, Lindell SD, Jennings NS, Head JC, Ford MJ. J Chem Soc Perkin Trans 1991;1:2603-2604.

69. Bolitt V, Chaguir B, Sinou D. Tetrahedron Lett 1992;33:2481-2484.

70. Arnau N, Moreno-Manas M, Pleixats R, Villarroya M. J Heterocyclic Chem 1995;32:1325-1334.

71. The reaction of $\mathbf{2 0 a}$ with $\mathbf{3 a}$ in the presence of $4 \mathrm{~mol} \% \mathbf{2 b}$ also occurred with high branched-to-linear selectivity (90:10) and enantioselectivity (92\% ee). However, the N9:N7 selectivity is reduced to $83: 17$.

72. The preference for N9-selectivity was confirmed by NMR spectroscopy (HMBC) for compound 21e. See the Supporting Information for additional details.

73. De Clercq E. Med Res Rev 2008;28:929-953. [PubMed: 18438800]

74. De Clercq E. Future Virol 2006;1:709-715.

75. Cihlar T, Delaney WE IV, Mackman R. Modified Nucleosides 2008:601-630.

76. Tillmann HL. Therapeut Clin Risk Manag 2008;4:797-802.

77. Brown HC, Chen J. J Org Chem 1981;46:3978-3988.

78. Kabalka GW, Shoup TM, Goudgaon NM. J Org Chem 1989;54:5930-5933.

79. Phan TB, Breugst M, Mayr H. Angew Chem Int Ed 2006;45:3869-3874.

80. Brotzel F, Chu YC, Mayr H. J Org Chem 2007;72:3679-3688. [PubMed: 17411095]

81. Bordwell FG. Acc Chem Res 1988;21:456-463.

82. Product ratios for competition experiments in the absence of potassium phosphate base are as follows: 18:82 (11a:28) for the competition reaction between imidazole and benzyl amine; 40:60 (11a:29) for the competition reaction between imidazole and aniline; 50:50 (11a:5a) for the competition reaction between imidazole and benzimidazole; and 30:70 (11a:21k) for the competition reaction between imidazole and bis-BOC-adenine.

83. Ramaswamy YS, Halesha R, Gowda NMN, Reddy GKN. Indian J Chem, Sec A 1991;30A:393-399.

84. Cuenca T, Padilla A, Royo P, Parra-Hake M, Pellinghelli MA, Tiripicchio A. Organometallics $1995 ; 14: 848-854$. 

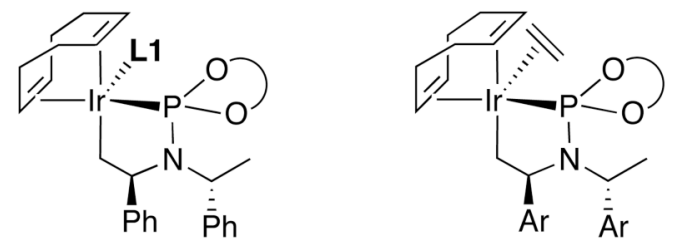

$\int_{\mathrm{O}}=(R)-\mathrm{BINOL}$

$\left[\operatorname{lr}(\mathrm{COD})\left(\mathrm{K}^{2}-\mathrm{L} \mathbf{1}\right)(\mathrm{L} \mathbf{1})\right](\mathbf{1})$

(1) $\left[\operatorname{lr}(\mathrm{COD})\left(\kappa^{2}-\mathrm{L} \mathbf{1}\right)(\right.$ ethylene $\left.)\right](2 a)$ $\left[\operatorname{Ir}(\mathrm{COD})\left(\kappa^{2}-\mathrm{L} 2\right)(\right.$ ethylene $\left.)\right](\mathbf{2 b})$

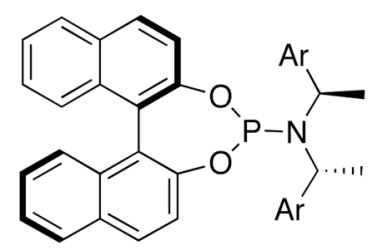

$\left(R_{\mathrm{a}}, R_{\mathrm{c}}, R_{\mathrm{c}}\right)-\mathrm{L} 1: \mathrm{Ar}=\mathrm{Ph}$

$\left(R_{\mathrm{a}}, R_{\mathrm{c}}, R_{\mathrm{c}}\right)-\mathrm{L} 2: \mathrm{Ar}=2-\mathrm{MeO}-\mathrm{C}_{6} \mathrm{H}_{4}$

Figure 1.

Cyclometalated Iridium Catalyst Precursors (1, 2a, and 2b) and Phosphoramidite Ligands (L1 and L2). 


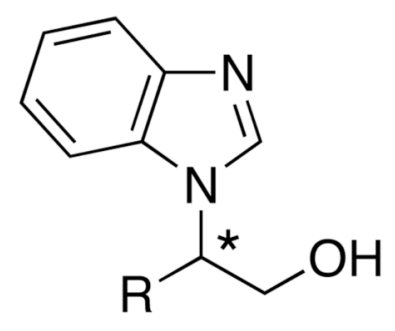<smiles>[R]C(C(=O)O)n1cnc2ccccc21</smiles><smiles>[R7][NH2+]C(=O)C([R])n1cnc2ccccc21</smiles><smiles>[R]C(CCO)n1cnc2ccccc21</smiles><smiles>[R]C(CC(=O)O)n1cnc2ccccc21</smiles><smiles>[R7]NC(=O)CC([R])n1cnc2ccccc21</smiles>

Figure 2.

Chiral Substructures of Biologically Active Benzimidazoles 


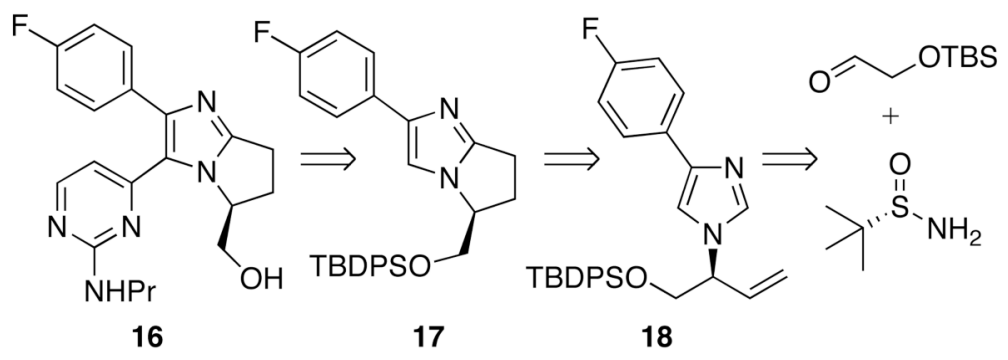

Figure 3.

Bergman and Ellman's Retrosynthesis of JNK3 Inhibitor 16 

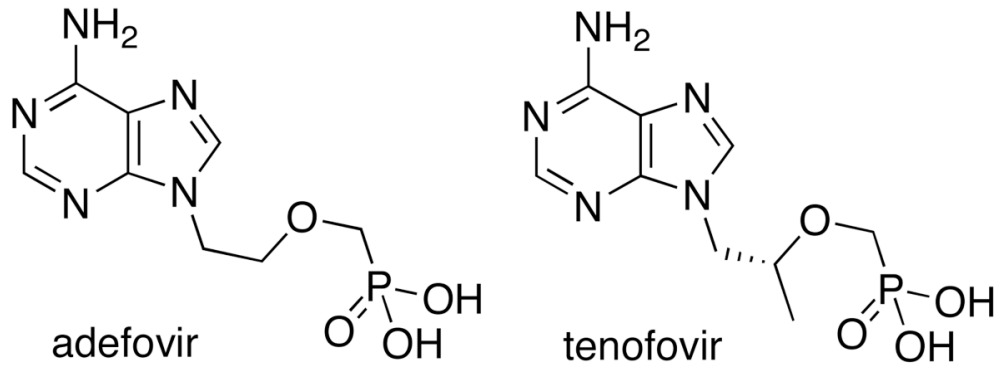

Figure 4.

Adenine Derivatives that are Reverse Transcriptase Inhibitors 


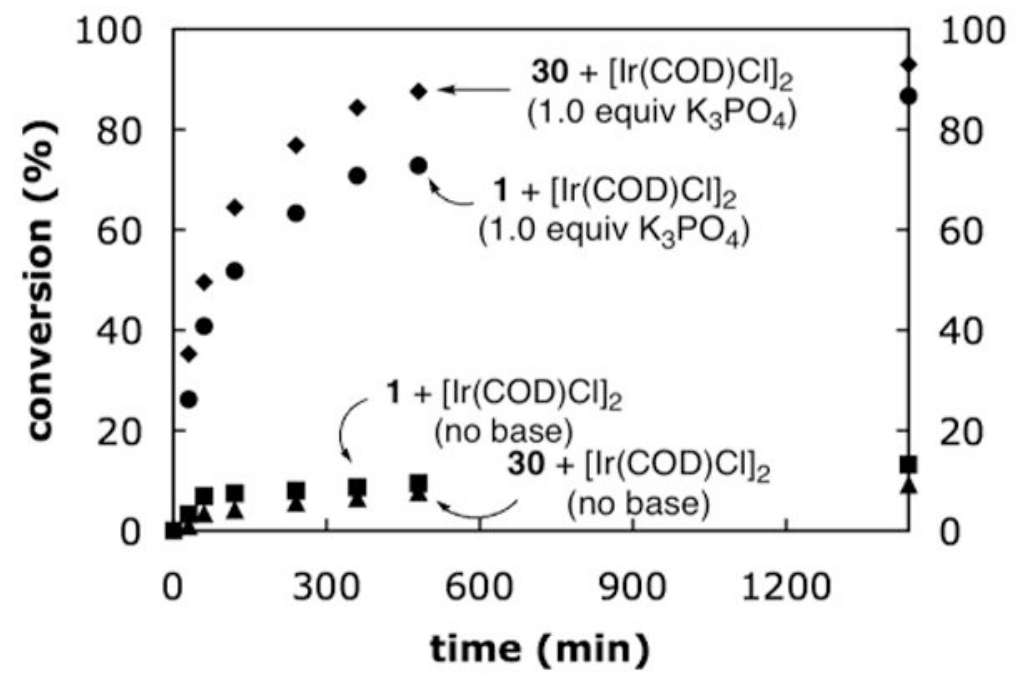

Figure 5.

A comparison of catalysts $\left[\operatorname{Ir}(C O D)\left(\kappa^{2}-\mathbf{L 1}\right)(\mathbf{L 1})\right](\mathbf{1})$ and $\left[\operatorname{Ir}(C O D)\left(\kappa^{2}-\mathbf{L 2}\right)(\mathbf{L 2})\right](30)$ for the reaction of methyl cinnamyl carbonate with benzimidazole in the presence and absence of $\mathrm{K}_{3} \mathrm{PO}_{4}$. All reactions were conducted in THF solvent at room temperature. Catalysts and conditions: $\mathbf{a}, 2 \mathrm{~mol} \% \mathbf{1}+1 \mathrm{~mol} \%[\operatorname{Ir}(\mathrm{COD}) \mathrm{Cl}]_{2}$ (no base); $\mathbf{\Delta}, 2 \mathrm{~mol} \% \mathbf{3 0}+1 \mathrm{~mol} \%[\mathrm{Ir}$ $(\mathrm{COD}) \mathrm{Cl}_{2}$ (no base); •, $2 \mathrm{~mol} \% \mathbf{1}+[\mathrm{Ir}(\mathrm{COD}) \mathrm{Cl}]_{2}+1.0$ equivalent $\mathrm{K}_{3} \mathrm{PO}_{4} ;>, 2 \mathrm{~mol} \% 30$ $+1 \mathrm{~mol} \%[\mathrm{Ir}(\mathrm{COD}) \mathrm{Cl}]_{2}+1.0$ equivalent $\mathrm{K}_{3} \mathrm{PO}_{4}$. 


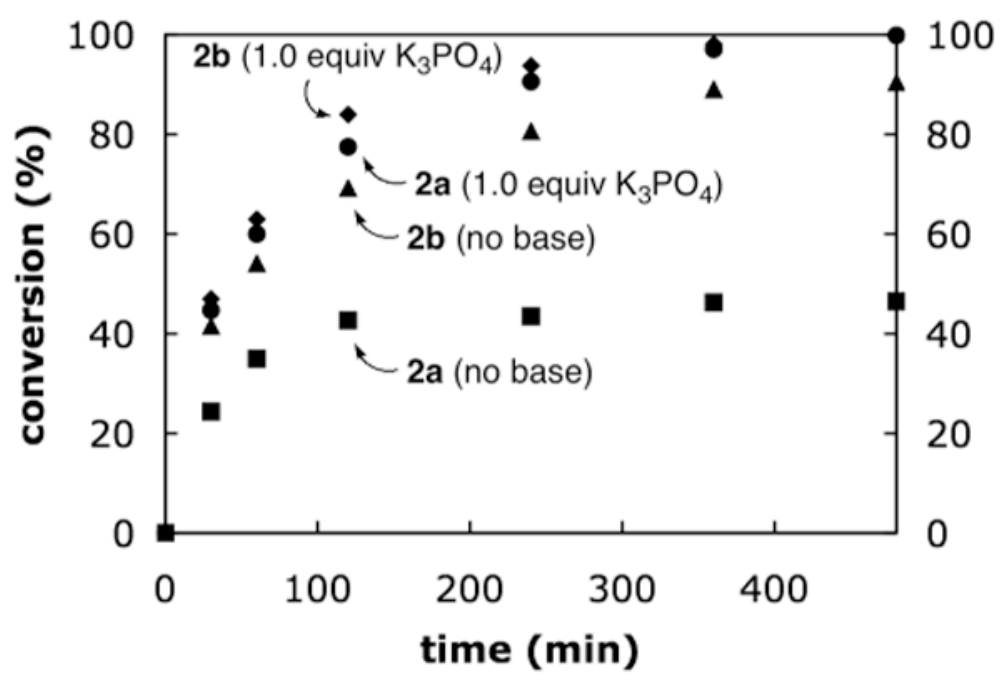

Figure 6.

A comparison of catalysts $\left[\operatorname{Ir}(\mathrm{COD})\left(\kappa^{2}-\mathbf{L} \mathbf{1}\right)(\right.$ ethylene $\left.)\right](\mathbf{2 a})$ and $\left[\operatorname{Ir}(\mathrm{COD})\left(\kappa^{2}-\mathbf{L} \mathbf{2}\right)(\right.$ ethylene $\left.)\right]$ (2b) for the reaction of methyl cinnamyl carbonate with benzimidazole in the presence and absence of $\mathrm{K}_{3} \mathrm{PO}_{4}$. All reactions were conducted in THF solvent at room temperature. Catalysts and conditions: $\mathbf{\square}, 2$ mol \% $\mathbf{2 a}$ (no base); $\mathbf{\Delta}, 2$ mol \% $\mathbf{2 b}$ (no base); $\bullet, 2 \mathrm{~mol} \% \mathbf{2 a}+1.0$ equivalent $\mathrm{K}_{3} \mathrm{PO}_{4} ;, 2$ mol \% $\mathbf{2 b}+1.0$ equivalent $\mathrm{K}_{3} \mathrm{PO}_{4}$. 

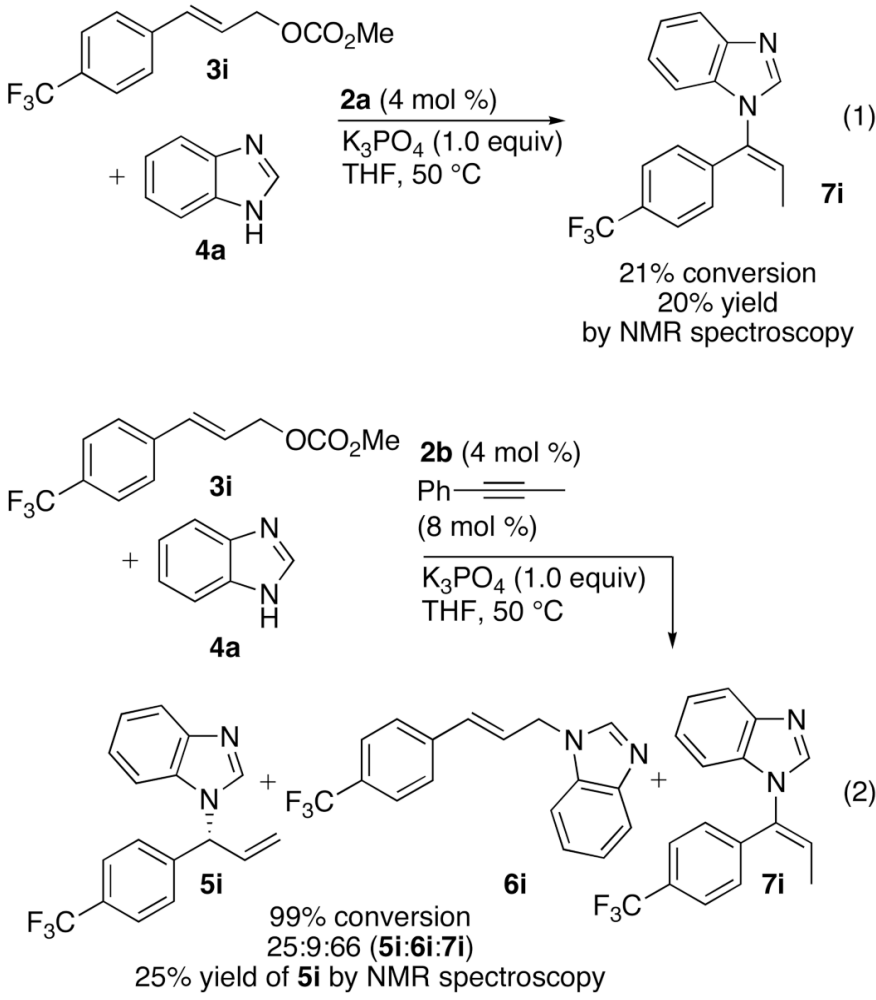

Scheme 1.

Limitations on the Iridium-Catalyzed Allylation of Benzimidazole 


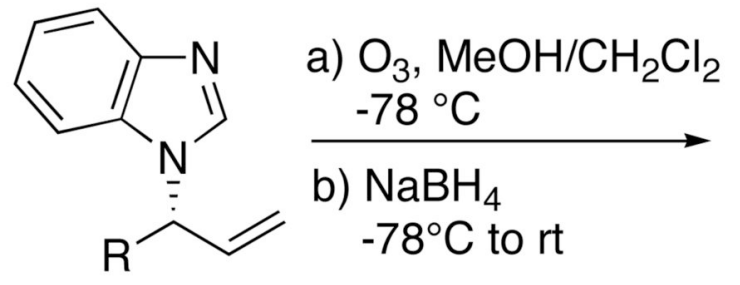

5a: $\mathrm{R}=\mathrm{Ph}, 97 \%$ ee

5h: $\mathrm{R}=\mathrm{C}_{3} \mathrm{H}_{7}, 94 \%$ ee

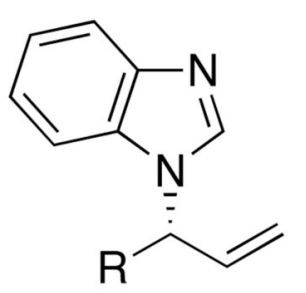

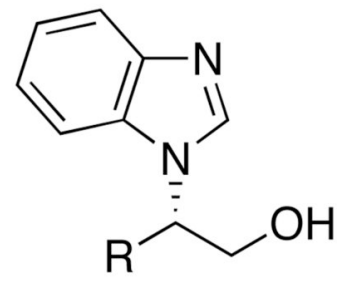

8a: $\mathrm{R}=\mathrm{Ph}, 84 \%$ yield, $97 \%$ ee 8b: $\mathrm{R}=\mathrm{C}_{3} \mathrm{H}_{7}, 93 \%$ yield, $94 \%$ ee 5a: $\mathrm{R}=\mathrm{Ph}, 97 \%$ ee

5h: $\mathrm{R}=\mathrm{C}_{3} \mathrm{H}_{7}, 94 \%$ ee<smiles>OCC[C@@H](c1ccccc1)n1cnc2ccccc21</smiles>

9a, $97 \%$ ee

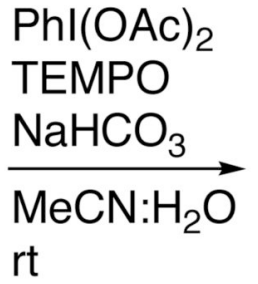

10, $74 \%$ yield, $99 \%$ ee (after recrystallization)<smiles>O=C(O)C[C@H](c1ccccc1)n1cnc2ccccc21</smiles>

9a: $\mathrm{R}=\mathrm{Ph}, 85 \%$ yield, $97 \%$ ee

9b: $\mathrm{R}=\mathrm{C}_{3} \mathrm{H}_{7}, 91 \%$ yield, $94 \%$ ee

Scheme 2.

Synthesis of Chiral $\alpha$-Benzimidazolyl Alcohols, $\beta$-Benzimidazolyl Alcohols, and $\beta$ Benzimidazolyl Acids 


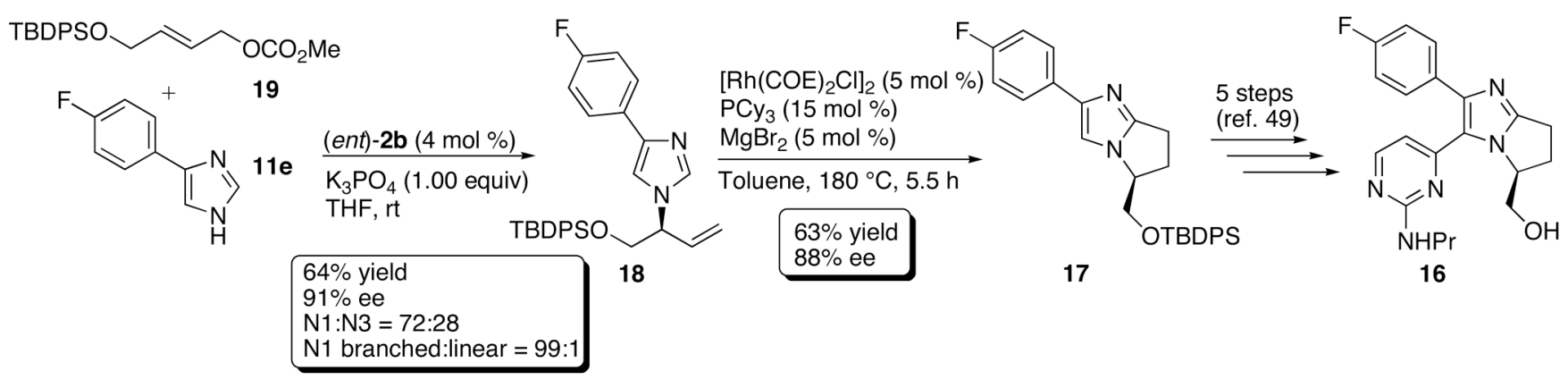

Scheme 3.

Direct Synthesis of $\mathbf{1 8}$ by Iridium-Catalyzed Allylic Substitution as a Formal Synthesis of JNK3 Inhibitor 16 
<smiles>[R7]C=CCOC(=O)O[R2]#CCn1cnc2c(P)nc([R1])nc21</smiles>

Scheme 4.

Potential Products from an Iridium-Catalyzed Allylation of Purine Nucleophiles 
<smiles>[R]C(C=C)n1cnc2c([N+](=O)[O-])ncnc21</smiles><smiles>[R]C(CO)n1cnc2c([N+](=O)OC)ncnc21</smiles>

21j: $\mathrm{R}=\mathrm{Ph}, 96 \%$ ee

21I: $\mathrm{R}=\mathrm{C}_{3} \mathrm{H}_{7}, 96 \%$ ee

25a: $\mathrm{R}=\mathrm{Ph}, 89 \%$ yield, $96 \%$ ee<smiles>CNc1ncnc2[nH]cnc12</smiles><smiles>[R]CC=C</smiles>

a) $9-\mathrm{BBN}$, THF

b) $30 \% \mathrm{H}_{2} \mathrm{O}_{2}$ $\mathrm{EtOH}, 3 \mathrm{M} \mathrm{NaOH}$ $0^{\circ} \mathrm{C}$ to rt

26a: $R=P h, 96 \%$ ee

25b: $\mathrm{R}=\mathrm{C}_{3} \mathrm{H}_{7}, 88 \%$ yield, $96 \%$ ee

26b: $R=\mathrm{C}_{3} \mathrm{H}_{7}, 96 \%$ ee<smiles>[R]C(CCO)n1cnc2c(NC)ncnc21</smiles>

27a: $R=P h, 82 \%$ yield, $96 \%$ ee

27b: $\mathrm{R}=\mathrm{C}_{3} \mathrm{H}_{7}, 77 \%$ yield, $96 \%$ ee

Scheme 5.

Synthesis of New Chiral Derivatives of Adenine Analogue Antivirals 

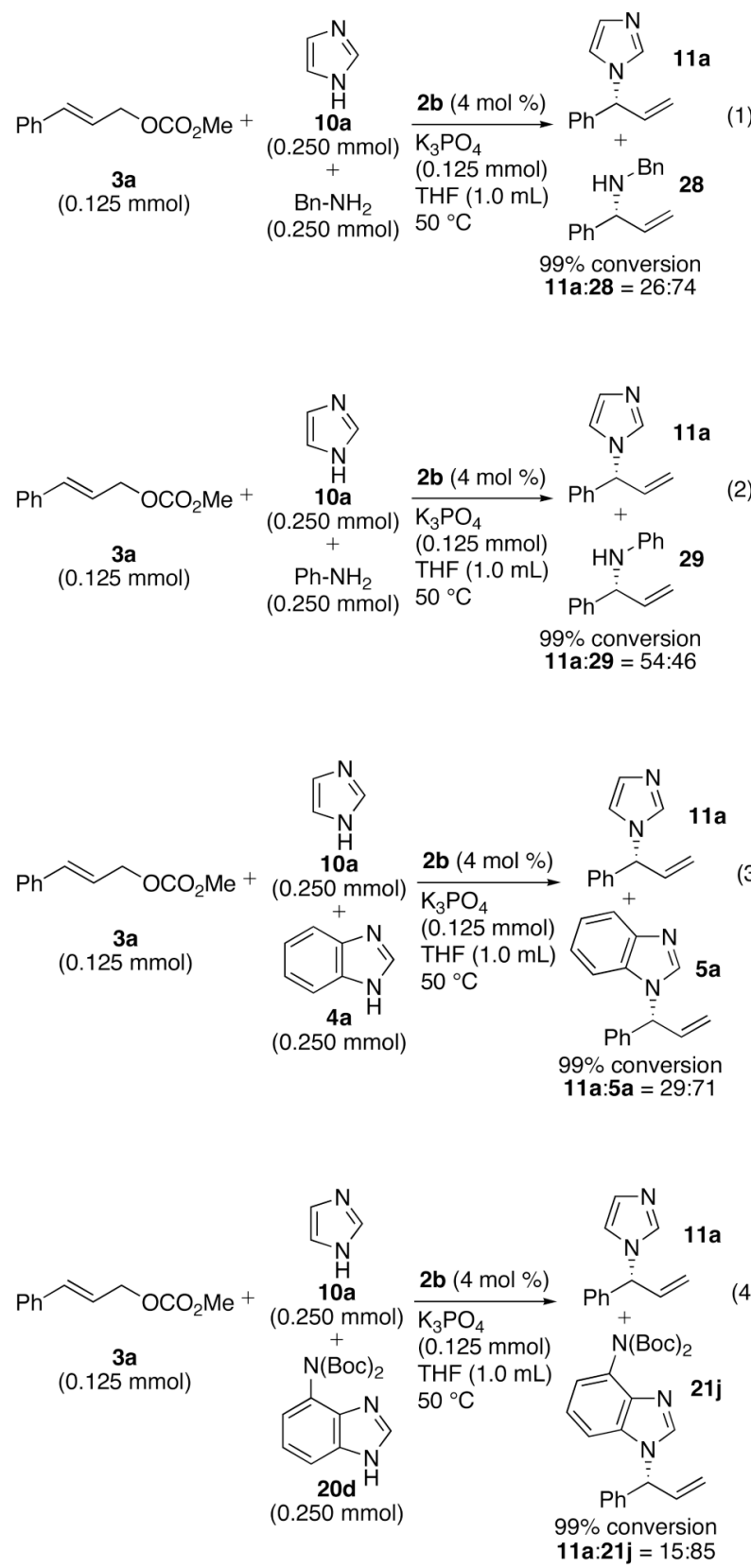

Scheme 6.

Competition Experiments between Imidazole and Amine or Heterocyclic Nitrogen Nucleophiles 
<smiles>CC(=O)OC/C=C/c1ccccc1</smiles>

$4 a$

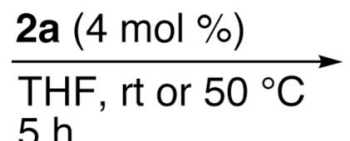
$5 \mathrm{~h}$<smiles>C=C[C@H](c1ccccc1)n1c[nH+]c2ccccc21</smiles>

$5 a$

$6 a$

room temperature $68 \%$ conversion

$5 \mathbf{a}: 6 \mathbf{a}=98: 2$ $50^{\circ} \mathrm{C}$

$52 \%$ conversion

$5 \mathbf{a}: 6 \mathbf{a}=98: 2$<smiles>CC(=O)OC/C=C/c1ccccc1</smiles>

$4 a$

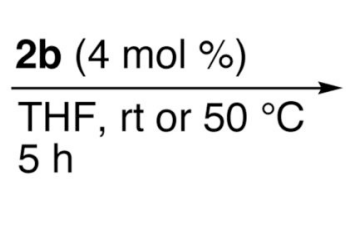<smiles>C=C[C@@H](c1ccccc1)n1cnc2ccccc21</smiles>

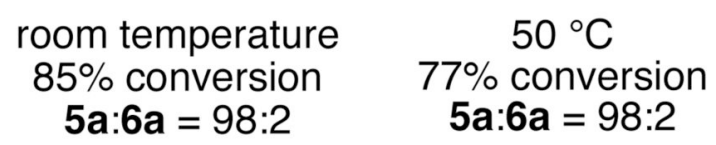

Scheme 7.

Allylation of Benzimidazole with 3a in the Absence of Exogenous Base 


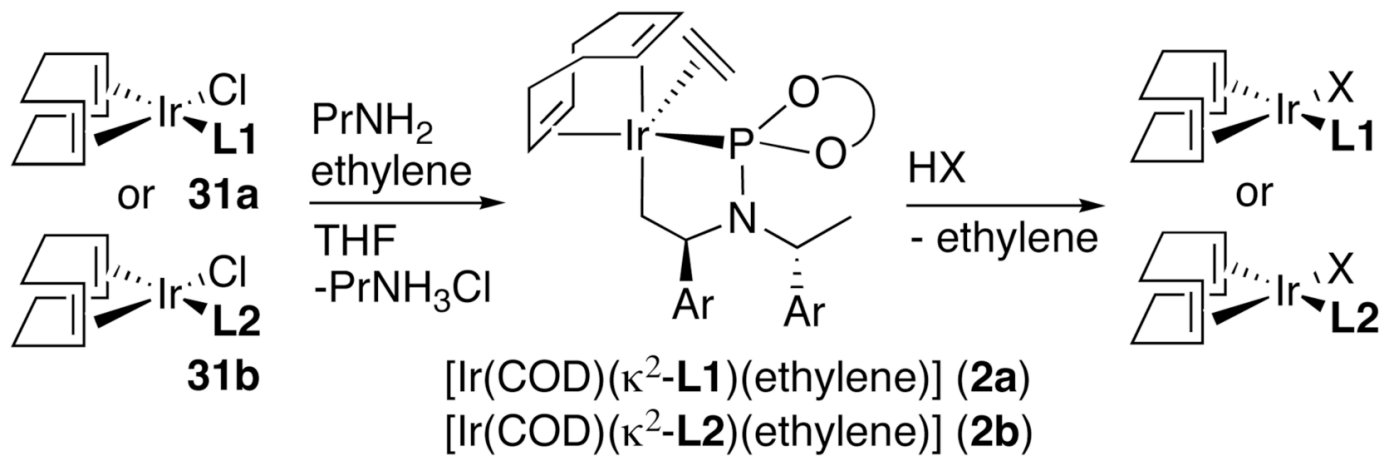

Scheme 8.

Cyclometallation to Form Iridium Metallacycles $\mathbf{2 a}$ and $\mathbf{2 b}$ and Ring Opening in the Presence of a Protic Acid 
<smiles></smiles>

$\left[\operatorname{lr}(C O D)\left(\kappa^{2}-L 1\right)\right.$ (ethylene)]

(s, $151.8 \mathrm{ppm})$

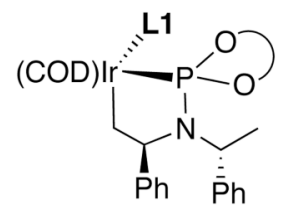

$+2 a$

$\stackrel{\leftarrow}{\text { - ethylene }}$

$\left[\operatorname{lr}(\mathrm{COD})\left(\kappa^{2}-\mathrm{L} \mathbf{1}\right)(\mathrm{L} \mathbf{1})\right](\mathbf{1})$

(d, $J=47 \mathrm{~Hz}, 153.5 \mathrm{ppm}$ )

(d, $J=47 \mathrm{~Hz}, 128.5 \mathrm{ppm}$ )

Scheme 9.

Mechanism for the Deactivation of $\left[\operatorname{Ir}(C O D)\left(\kappa^{2}-\mathbf{L 1}\right)(\right.$ ethylene $\left.)\right](\mathbf{2 a})$ in the Presence of Benzimidazole 


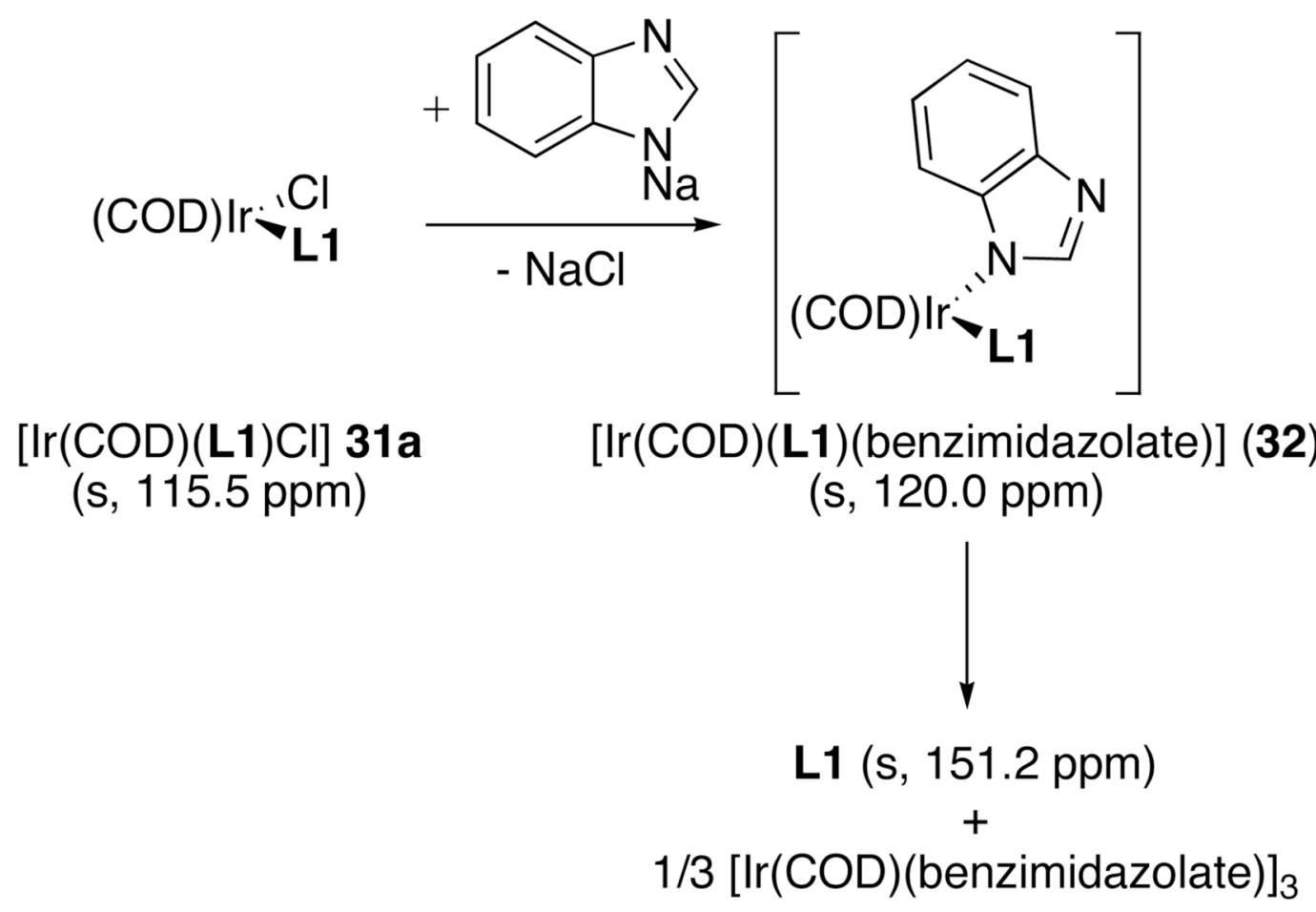

Scheme 10.

Independent Generation of [ $\operatorname{Ir}(\mathrm{COD})(\mathbf{L 1})$ (benzimidazolate)] 32 and Its Rapid Decomposition to Free Phosphoramidite Ligand $\mathbf{L 1}$ and $\left[\operatorname{Ir}(\mathrm{COD})(\text { benzimidazolate) }]_{3}\right.$ 


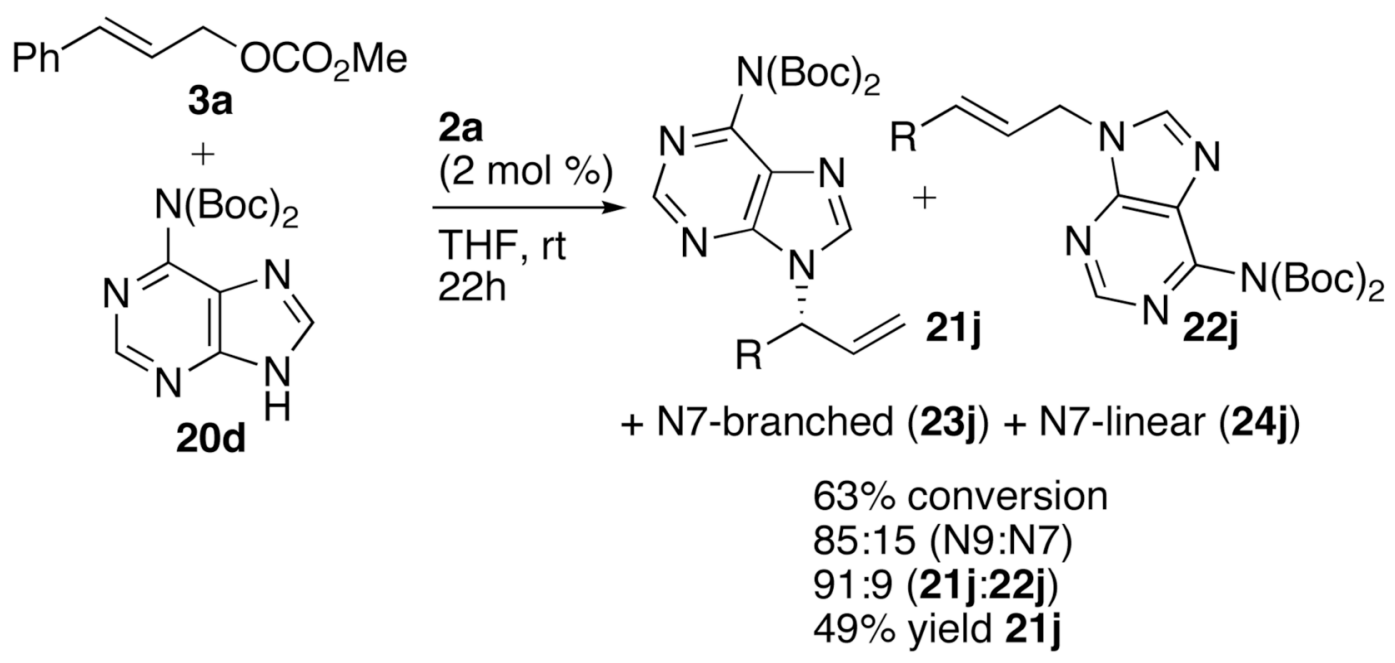

Scheme 11.

Base-Free $N$-Allylation of Bis-BOC-adenine 20d with 3a 


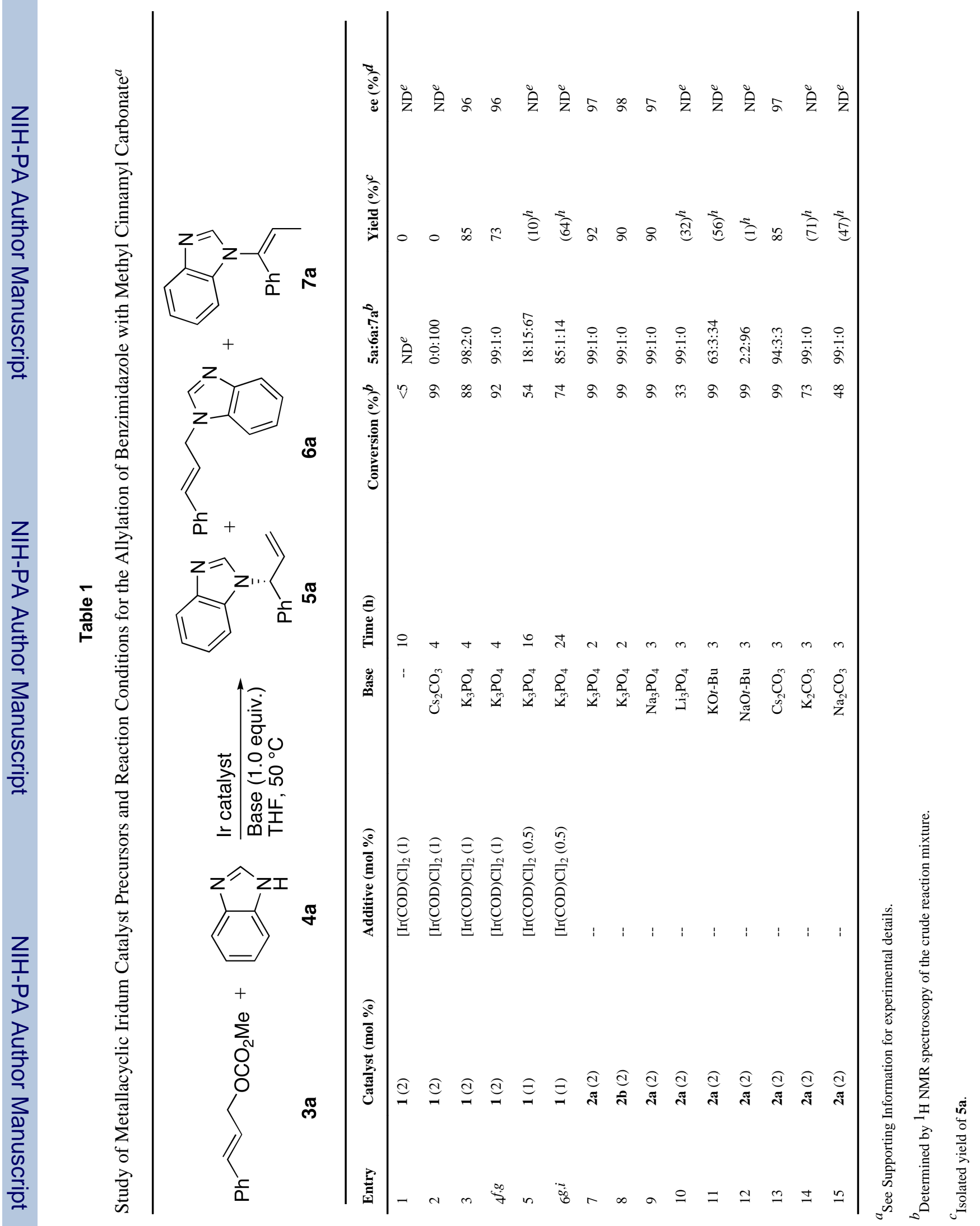




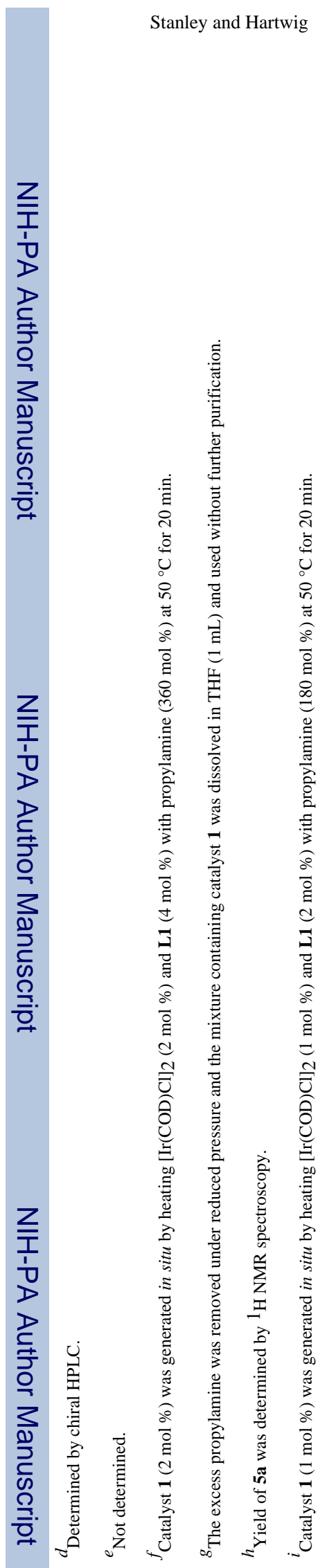

$J$ Am Chem Soc. Author manuscript; available in PMC 2010 July 1. 


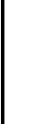

$\sim$
$\frac{0}{0}$
$\frac{0}{\sigma}$

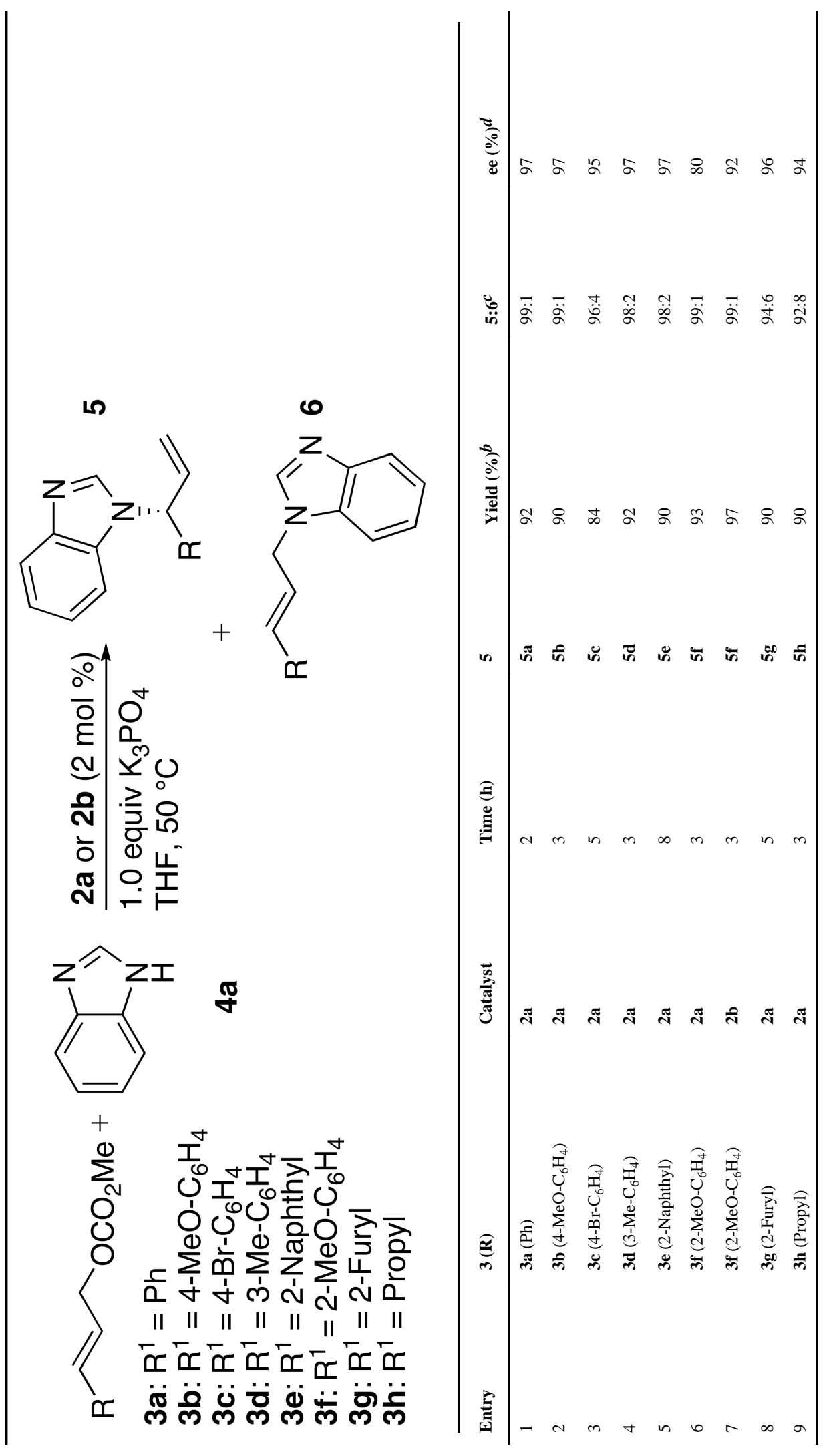

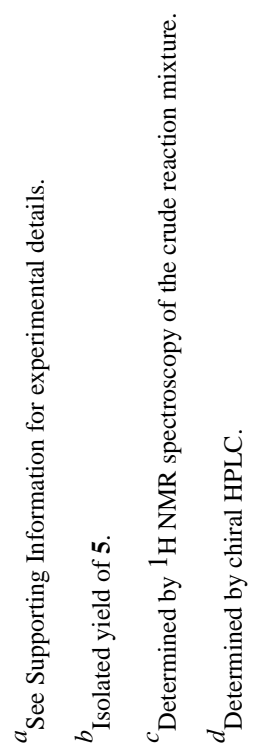

$J$ Am Chem Soc. Author manuscript; available in PMC 2010 July 1. 


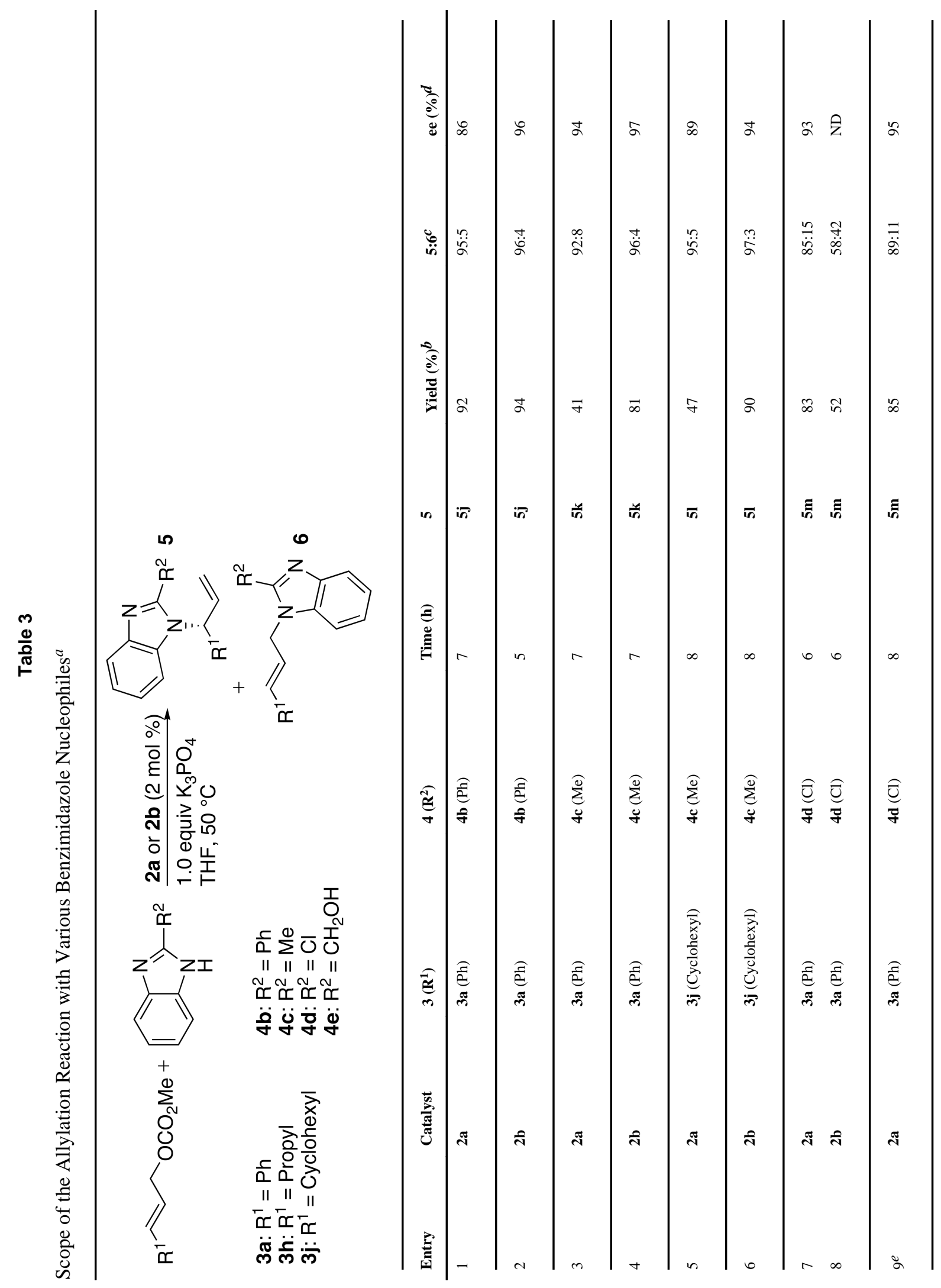




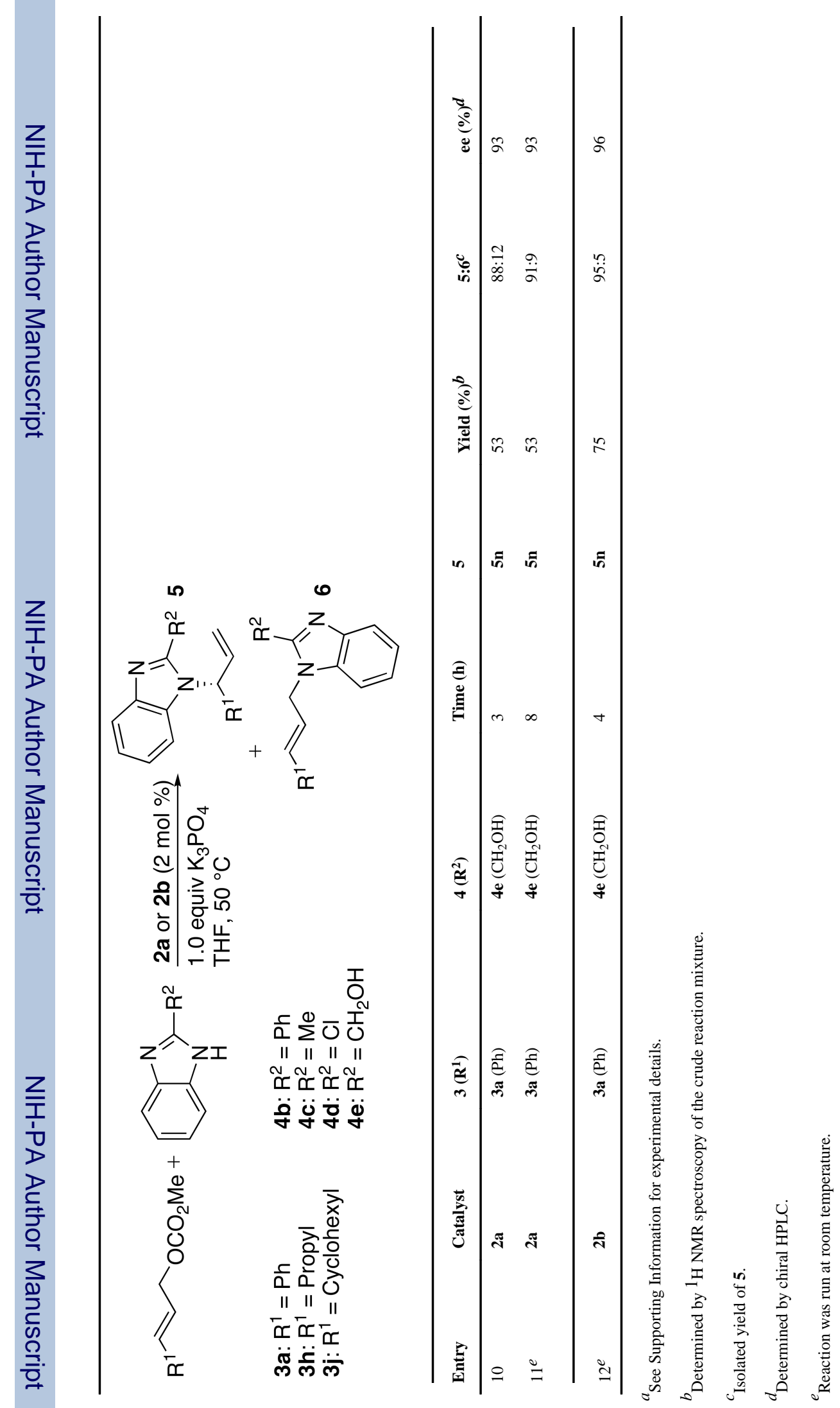




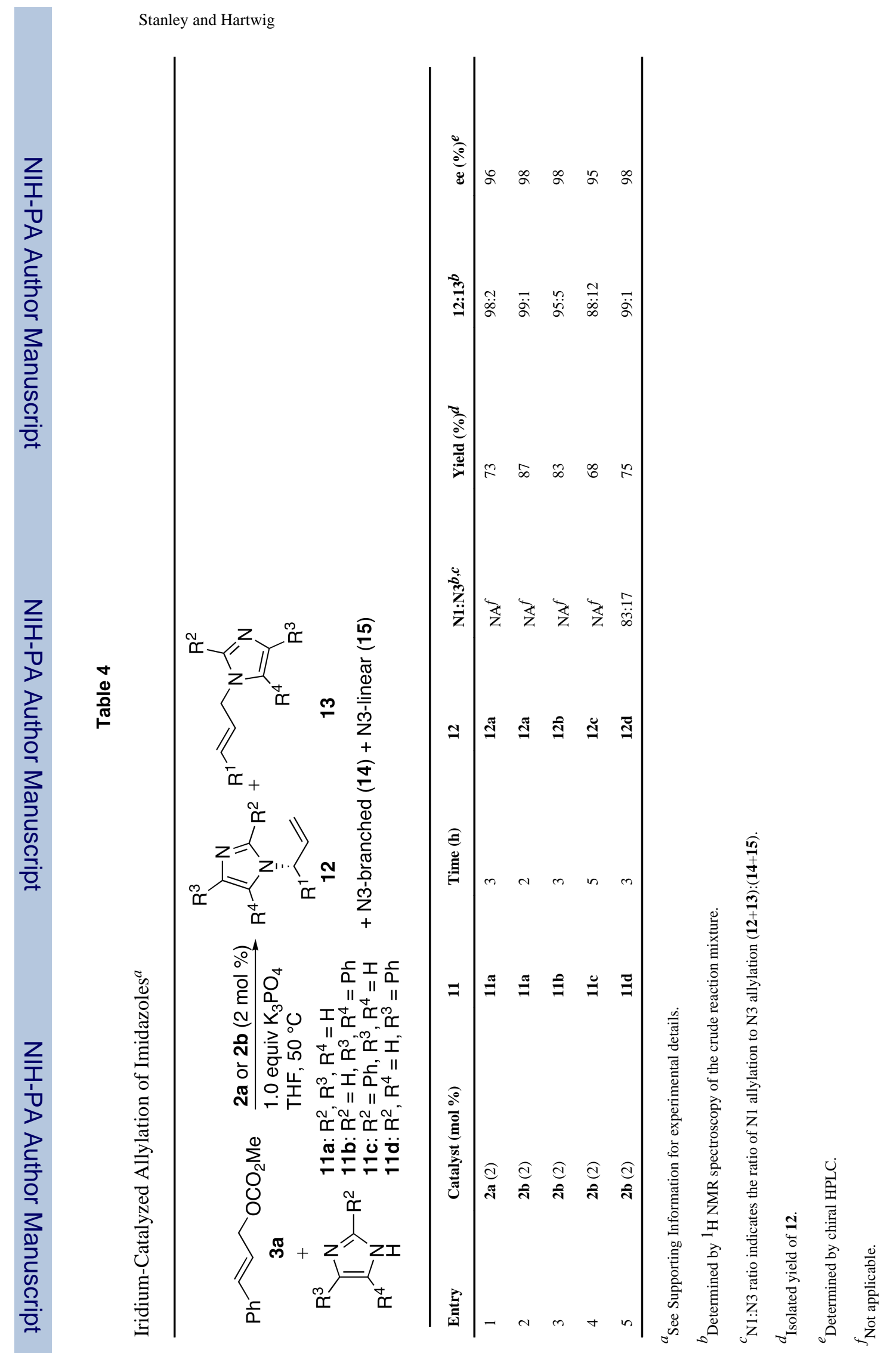

$J$ Am Chem Soc. Author manuscript; available in PMC 2010 July 1. 


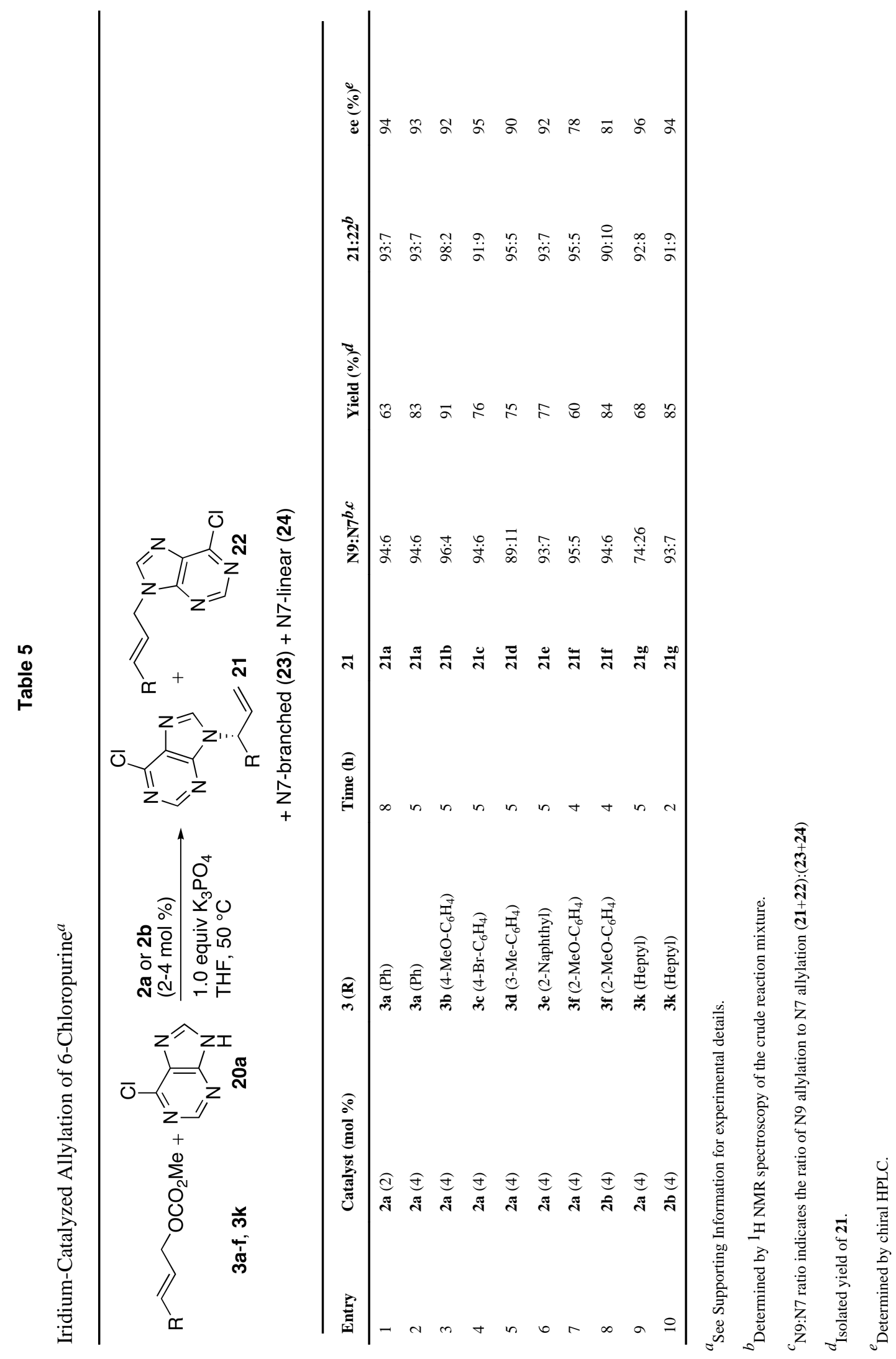




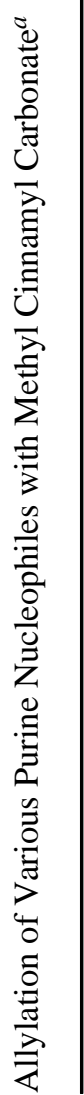

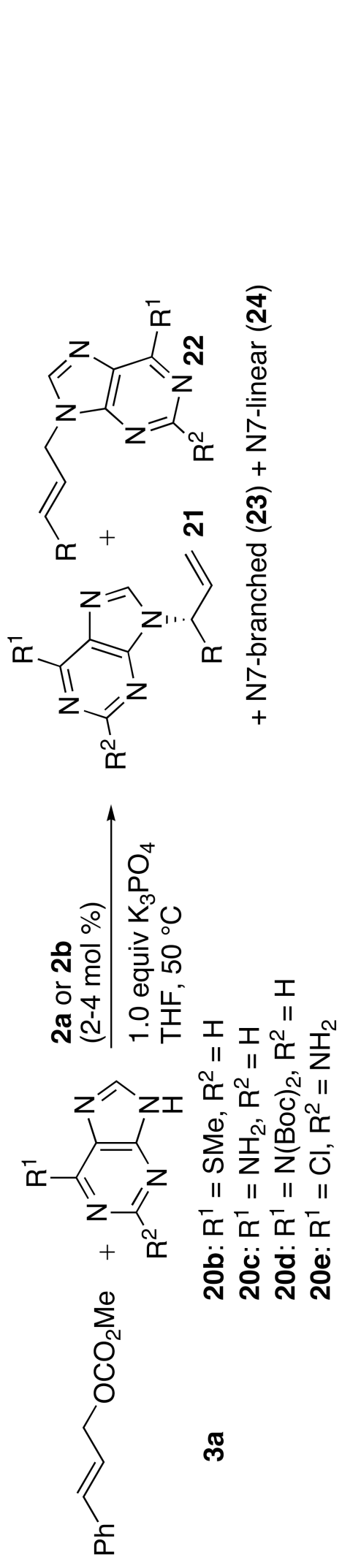

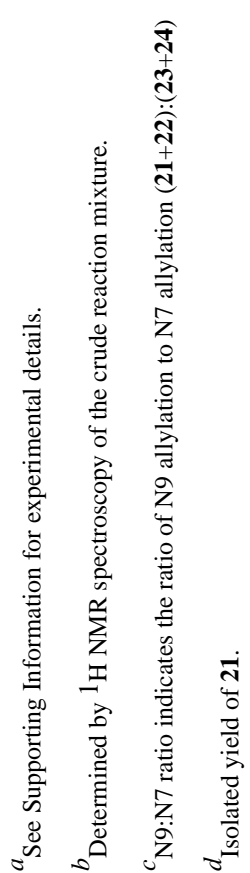




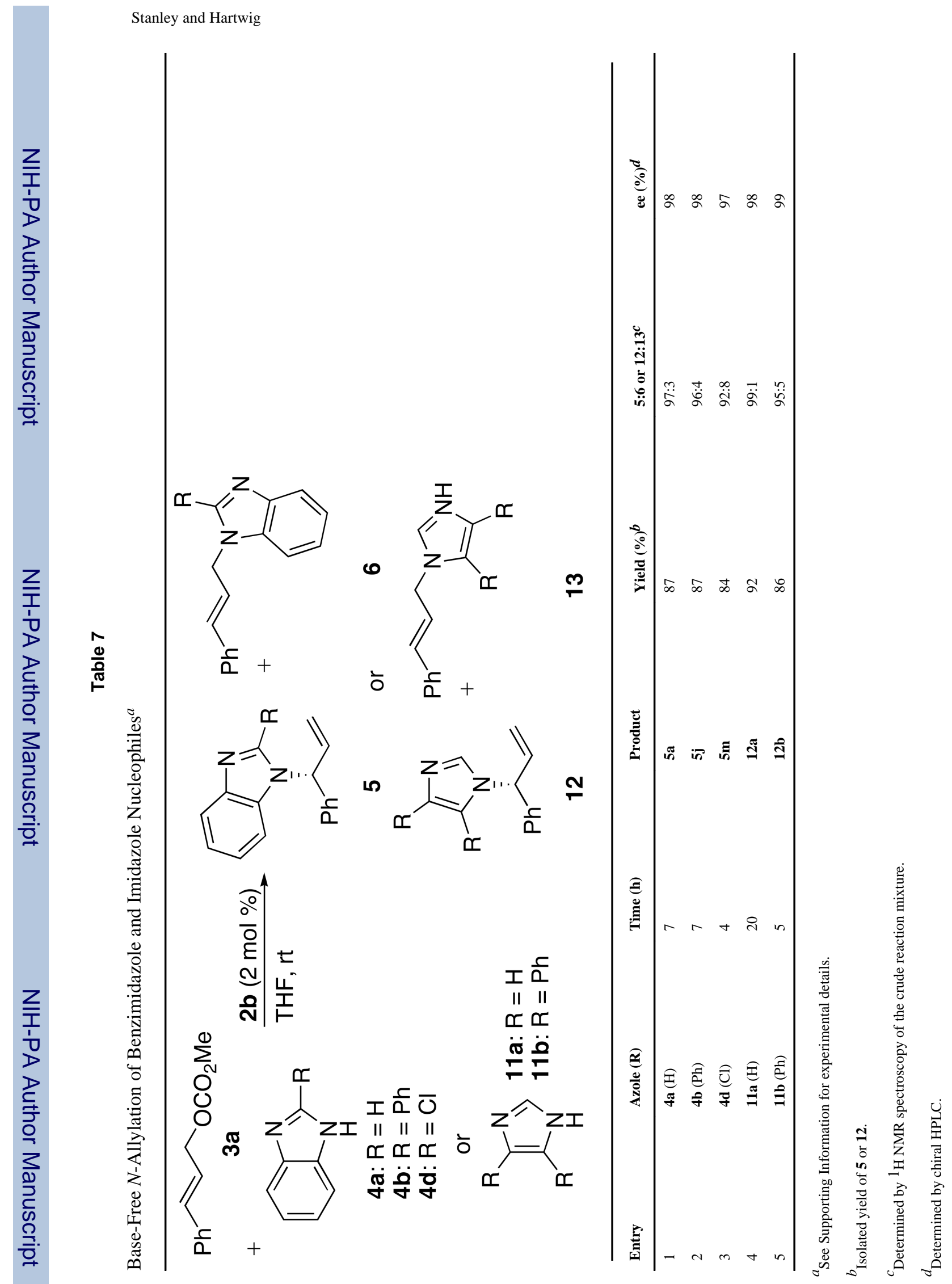

$J$ Am Chem Soc. Author manuscript; available in PMC 2010 July 1. 